\title{
NG2 Regulates Directional Migration of Oligodendrocyte Precursor Cells via Rho GTPases and Polarity Complex Proteins
}

\author{
Fabien Binamé, ${ }^{1}$ Dominik Sakry, ${ }^{1}$ Leda Dimou, ${ }^{2}$ Valérie Jolivel, ${ }^{3}$ and Jacqueline Trotter $^{1}$ \\ ${ }^{1}$ Molecular Cell Biology, Department of Biology, Johannes Gutenberg University of Mainz, D-55122 Mainz, Germany, ${ }^{2}$ Physiological Genomics, Ludwig- \\ Maximilians-University, 80539 Munich, Germany, and ${ }^{3}$ Department of Neurology, University Medicine Mainz, D-55131 Mainz, Germany
}

The transmembrane proteoglycan NG2 is expressed by oligodendrocyte precursor cells (OPC), which migrate to axons during developmental myelination and remyelinate in the adult after migration to injured sites. Highly invasive glial tumors also express NG2. Despite the fact that NG2 has been implicated in control of OPC migration, its mode of action remains unknown. Here, we show in vitro and in vivo that NG2 controls migration of OPC through the regulation of cell polarity. In stab wounds in adult mice we show that NG2 controls orientation of OPC toward the wound. NG2 stimulates RhoA activity at the cell periphery via the MUPP1/Syx1 signaling pathway, which favors the bipolar shape of migrating OPC and thus directional migration. Upon phosphorylation of Thr-2256, downstream signaling of NG2 switches from RhoA to Rac stimulation. This triggers process outgrowth through regulators of front-rear polarity and we show using a phospho-mimetic form of NG2 that indeed NG2 recruits proteins of the CRB and the PAR polarity complexes to stimulate Rac activity via the GEF Tiam1. Our findings demonstrate that NG2 is a core organizer of Rho GTPase activity and localization in the cell, which controls OPC polarity and directional migration. This work also reveals CRB and PAR polarity complexes as new effectors of NG2 signaling in the establishment of front-rear polarity.

\section{Introduction}

During CNS development oligodendrocyte precursor cells (OPC) migrate to axonal tracts over considerable distances where they then mature to myelinating oligodendrocytes (Sugimoto et al., 2001; Aguirre and Gallo, 2004; Simons and Trajkovic, 2006; Barres, 2008). Remyelination in the adult brain involves OPC migration to lesions (Aguirre et al., 2007). OPC express the chondroitin sulfate proteoglycan CSPG4/NG2/MCSP, hence called NG2, which modulates their migration (Niehaus et al., 1999; Nishiyama et al., 2009). NG2 expression is also associated with invasiveness in glioma and melanoma tumors (Campoli et al., 2010). Myelination requires migration of OPC in a precise direction. As in other examples of directed migration, OPC migration necessitates a polarization of the cell (Benninger et al., 2007; Binamé et al., 2010; Hall and Lalli, 2010) whose core regulators are Rho GTPases and polarity complex proteins (Fukata et al., 2003; Petrie et al., 2009). Cell polarity consists in a localized and

Received 0ct. 26, 2012; revised April 26, 2013; accepted May 17, 2013.

Author contributions: F.B. designed research; F.B., D.S., L.D., and V.J. performed research; F.B. analyzed data; F.B. and J.T. wrote the paper.

This work was supported by the Deutsche Forschungsgemeinschaft (F.B./J.T., TR1008/2-1; TR231/5-4) and the Friedrich Bauer Stiftung (L.D.). We thank Lilia Niedens and Ulrike Stapf for technical assistance and Khalad Karram for the establishment of the NG2-EYFP transgenic mouse. We thank Magdalena Götz for support in this study and Urszula Hibner and Robin White for critical comments on this manuscript.

The authors declare no competing financial interests.

Correspondence should be addressed to either Fabien Binamé or Jacqueline Trotter, Molecular Cell Biology, Department of Biology, Johannes Gutenberg University of Mainz, D-55122 Mainz, Germany, E-mail: biname@unimainz.de or trotter@uni-mainz.de.

DOI:10.1523/JNEUROSCI.5010-12.2013

Copyright $\odot 2013$ the authors $\quad 0270-6474 / 13 / 3310858-17 \$ 15.00 / 0$ asymmetrical distribution of signaling, adhesion molecules, and the cytoskeleton. In migrating cells, the polarity complexes PAR (Cdc42/Par3/Par6/aPKC) and CRB (Crumbs/Pals1/PATJ) relocate to the leading front and promote front-rear polarity (Etienne-Manneville, 2008).

Migration and process protrusion of oligodendrocyte progenitors involves continual remodeling of the cytoskeleton controlled by Rho-family GTPases, including Cdc42, Rac, and RhoA (Bacon et al., 2007; Bauer et al., 2009), which are activated by GTP loading via guanine nucleotide exchange factors (GEF) (Rossman et al., 2005). Together with Cdc42, Rac regulates actin polymerization, which initiates protrusive forces (Ridley, 2001), whereas RhoA ensures contraction of filamentous actin. The orientation of cell migration is determined by the location and frequency of process protrusion (Arrieumerlou and Meyer, 2005). RhoA is thought to contribute to persistent migration by limiting the number of cell protrusions through suppression of Rac activity mediated by ROCK (Vega et al., 2011).

NG2 is a transmembrane proteoglycan of 2327 aa comprising a short cytoplasmic domain of 76 aa (Stegmüller et al., 2003; Stallcup and Huang, 2008). Phosphorylation of Thr-2256 in the cytoplasmic domain by PKC $\alpha$ enhances cell motility (Makagiansar et al., 2007). The C-terminal PDZ-binding motif of NG2 has been found associated with several PDZ proteins including MUPP1 (Barritt et al., 2000), and NG2 influences the activity of the Rho GTPase Cdc42 in melanoma and Rac in astrocytoma (Eisenmann et al., 1999; Majumdar et al., 2003). This connection to GTPases suggests that NG2 may play a role in the regulation of polarity. Indeed, NG2 controls asymmetric division of OPC 
(Sugiarto et al., 2011) and activation of NG2 in astrocytoma induces a promigratory polarized shape (Stallcup and DahlinHuppe, 2001).

Here we show that NG2 regulates the polarity of OPC. NG2 activates RhoA at the membrane via MUPP1 and the GEF Syx1: this signaling pathway maintains the bipolar shape of OPC and enhances directional migration. Alternatively, phosphorylation of Thr-2256 modifies NG2 signaling, resulting in stimulation of Rac activity via the polarity complex protein PATJ and the GEF Tiam1. Whereas the stimulation of RhoA by NG2 limits protrusions, the switch to Rac stimulation is likely to regulate migration by promoting process outgrowth.

\section{Materials and Methods}

Cell culture. Oli-neu cells (Jung et al., 1995) were cultured at $37^{\circ} \mathrm{C}$, with $5 \% \mathrm{CO}_{2}$ and expanded in Sato medium containing $1 \%$ horse serum (DMEM, with $0.2 \%(\mathrm{w} / \mathrm{v})$ sodium bicarbonate, $0.01 \mathrm{mg} / \mathrm{ml}$ insulin, 0.01 $\mathrm{mg} / \mathrm{ml}$ transferrin, $220 \mathrm{~nm}$ sodium selenite, $100 \mu \mathrm{M}$ putrescine, $500 \mathrm{nM}$ triiodothyronine, $520 \mathrm{~nm}$ thyroxine, and $200 \mathrm{~nm}$ progesterone). All experiments were performed in Sato medium without progesterone and without serum on surfaces coated with poly-L-lysine. As described, in some experiments cells were incubated with basic fibroblast growth factor (bFGF) (tebu-bio). Inhibition of both ROCK1 and ROCK2 was performed by simultaneous addition to the medium of two structurally unrelated pharmacological inhibitors, $10 \mu \mathrm{M}$ Y27632 (Calbiochem) and $5 \mu \mathrm{M}$ H1152 (Calbiochem), $12 \mathrm{~h}$ before trypsinization and during the course of the experiment. Oli-neu cells were treated with $1 \mathrm{~mm}$ dbcAMP (Sigma) for $1 \mathrm{~d}$ to induce its differentiation then subjected to biochemical analysis $1 \mathrm{~d}$ later. Primary oligodendrocyte cultures were prepared from embryonic day 14-16 mice as described previously (Krämer et al., 1997).

RNA interference. siRNA oligos were purchased from Qiagen and transfected into Oli-neu cells and primary oligodendrocytes in suspension with AMAXA electroporation system using protocol for primary neural cells. The targeted sequences of mouse cDNA were as followed: siNG2 [5'-AAGTCAGCTCACTGCAGAAAA-3']; siMUPP1 [5'-GCGA AAGGCTACACATGAT-3' ] (Adachi et al., 2009); siPatj [5'-GTGAAG TGACCAGATCTTA-3'] (Adachi et al., 2009); siSyx1 [5'-CTCACTGC CTCGGAGGTGTGA-3'] (adapted from Liu and Horowitz, 2006); siTiam1 [5'-GCGAAGGAGCAGGTTTTCT-3'] (Malliri et al., 2004); siPals1 [5'-GTTCATTGAACATGGTGAA-3'] (van Rossum et al., 2006); siPar6c [5'-CCAGCGTAATAATGTGGTA-3'] (Zhang and Macara, 2008); siDlg1 [5'-AGGTCCTAAAGGTCTTGGG-3'] (Cotter et al., 2010); siDia1 [5'-GCTGGTCAGAGCCATGGAT-3'] (Goh et al., 2011); siCrb2 [5'-CTGTGAGGAGGTTCCAGAT-3'] (Boroviak and Rashbass, 2011); si $\beta$-PIX [5'-ACCAATCTATAGGCTGACTTC-3'] (Lee et al., 2005); siPar3 [5'-GACCCAGCTTTAACTGGCCTTTCCA-3'] (Ishiuchi and Takeichi, 2011); and siSyntenin [equimolar mix of 5' $5^{\prime}$ TACGTCAG CATAGTACATTTA-3' and 5'-CAGATTGCAGATATACTGTCA-3'] (Chatterjee et al., 2008). The nonsilencing siRNA siControl [5'-AATTCT CCGAACGTGTCACGT-3'] was used as a control.

Exponentially growing Oli-neu cells were infected with the retroviral vector pSIREN-RetroQ encoding hairpin shRNA sequences directed against firefly luciferase (shLuc) as a control (coming from RNAi-Ready pSIREN-RetroQ Retroviral Vector kit, Clontech) or against NG2 (the hairpin sequences added in the vector were as followed: shNG2 forward [5' -gatccgcAAGTCAGCTCACTGCAGAAAttcaagagaTTTCTGCAGTGA GCTGACTTgcttttttcaattg- $\left.3^{\prime}\right]$; shNG2 reverse [5'-aattcaattgaaaaaagcAAGT CAGCTCACTGCAGAAAtctcttgaaTTTCTGCAGTGAGCTGACTTgcg$\left.3^{\prime}\right]$ ). Stable populations were selected with $4 \mu \mathrm{g} / \mathrm{ml}$ puromycin for $3 \mathrm{~d}$.

Expression vectors. NG2 expression vectors consist of a partial coding sequence of mouse NG2 (Stegmüller et al., 2003), resulting in the expression of a deletion mutant (NG2del). NG2del consists of the signal sequence, one-fourth of the N-terminal extracellular portion (including both laminin G-type motifs), the transmembrane domain, and the complete intracellular region. NG2del cDNA was cloned in pIREShyg2 (Clontech) and a Flag tag was introduced at the position of the deleted part of NG2, i.e., in the extracellular part next to the transmembrane domain, resulting in the following protein sequence: $\mathrm{N}$-terminal extra- cellular portion (477 aa)-PAGA-Flag(DYKDDDDK)-KGGFLGFLEANtransmembrane and intracellular portion (101 aa). The NG2trunk construct was generated by removing the sequence corresponding to the three last amino acids of the PDZ-binding motif at the C-terminal end.

NG2del mutants in which threonine 2256 was replaced by either valine (NG2del-T2256V) or glutamic acid (NG2del-T2256E) were made using QuikChange Site-Directed Mutagenesis kit (Stratagene) with overlapping pairs of oligonucleotide primers containing appropriately altered codons. NG2del mutants cloned in pIREShyg2 vector were transiently transfected with FuGENE HD (Promega). To generate stable expression, the portion of pIREShyg 2 vectors containing the CMV promoter, NG2del mutant cDNA, the hygromycin resistance gene, and the poly A signal was subcloned in the retroviral pSIREN-RetroQ backbone. Exponentially growing Oli-neu cells were infected with the retroviral vectors and stable populations were selected with $0.3 \mathrm{mg} / \mathrm{ml}$ hygromycin for $3 \mathrm{~d}$.

Antibodies. The following primary monoclonal antibodies were used: AN2 anti-NG2 (Niehaus et al., 1999); anti-PLP (clone aa3; Yamamura et al., 1991); anti-MUPP1, anti-Rac1, and anti-PDGFR $\alpha$ (BD Biosciences); anti-RhoA (Santa Cruz Biotechnology); and anti-Flag (M2; Sigma). The following primary polyclonal antibodies were used: anti- $\gamma$-tubulin and anti-bFGF (Sigma); anti-syntenin (Synaptic Systems); anti-GAPDH (Bethyl Laboratories); anti-ezrin (Millipore); anti-Syx (PLEKHG5; ProteinTech Group), anti- $\beta$-PIX, anti-Par3, and anti-DCX (Millipore); anti-GFP (Abcam); anti-GFAP (Dako); anti-PATJ; anti-Tiam1 (C-16); and anti-Pals1 (H-250) antibodies (Santa Cruz Biotechnology). Fluorochrome-labeled secondary antibodies were purchased from Dianova.

RNA isolation and analysis. Total RNA was extracted with High Pure RNA Isolation kit (Roche) and analyzed by semiquantitative reverse transcription-PCR. First strand cDNA was synthetized with polydT then amplified with Crimson TaqDNA polymerase (New England BioLabs) according to the manufacturer's instructions. The primers sequences used were as followed: GAPDH-Forward [5'-GCTCACTGGCATGGCCTTCCG-3']; GAPDH-Reverse [5'-TGGAAGAGTGGGAGTTGCTGT-3']; Par6-Forward [5'-TCGTCGAGGTGAAGAGCAAAT-3']; Par6-Reverse [5'-AGCA TCCGTATAGCCAAGCAG-3']; Dlg1-Forward [5'-GAAACGAGTGATGC TGACCAG-3']; Dlg1-Reverse [5'-ACGCTTCGGTCTAGTTGTATGA-3']; Dial-Forward [5'-CGACGGCGGCAAACATAAG-3']; Dia1-Reverse [5'TGCAGAGGAGTTTCTATGAGCA-3'] ; Crb2-Forward [5'-CATCCCCA CCTTCAAGTCTG-3'] ; Crb2-Reverse [5'-CAAAGCTGAGCATCACCA AG-3'].

Western-blot analysis, immunoprecipitation, and pull-down assay. Cells were scraped off on ice and homogenized in lysis buffer (radioimmunoprecipitation assay buffer for Figs. 1, 3, and specific lysis buffer for immunoprecipitation or pull-down assay) with protease inhibitors. Cell lysates were cleared of cellular debris and nuclei by a $10,000 \times g$ centrifugation step for $2 \mathrm{~min}$. Lysates were denatured with Laemmli loading buffer containing $400 \mathrm{~mm}$ dithiothreitol, analyzed by SDS-PAGE and blotted onto PVDF membranes. Blots were incubated overnight at $4^{\circ} \mathrm{C}$ with primary antibodies, then incubated with horseradish peroxidaseconjugated secondary antibodies (Dianova) and activity was visualized by enhanced chemiluminescence (ECL).

To perform immunoprecipitation and pull-down assays on a large number of migrating Oli-neu cells, a multiple wound procedure was applied to scale up the number of scratch-activated cells (adapted from Etienne-Manneville, 2006). Multiple scratches were performed in confluent monolayers of Oli-neu cells plated on $60 \mathrm{~mm}$ dishes. A multichannel pipette with $20-200 \mu \mathrm{l}$ tips was used to perform six circular scratches and nine linear scratches across the plate, repeated six times by turning the plate a $15^{\circ}$ angle each time. Cells were incubated for $4 \mathrm{~h}$ then lysed.

Immunoprecipitation was performed with EZview Red ANTI-FLAG M2 Affinity Gel Beads (Sigma) according to the manufacturer's instructions. Briefly, cells were extracted with Tris- $\mathrm{HCl}$ lysis buffer ( $50 \mathrm{~mm}$ Tris- $\mathrm{HCl}, \mathrm{pH}$ 7.4, $150 \mathrm{~mm} \mathrm{NaCl}, 1 \mathrm{~nm}$ EDTA, $1 \%$ Triton X-100) and centrifuged for $10 \mathrm{~min}$ at $8200 \times g$. The supernatant was incubated for $2 \mathrm{~h}$ with the beads. Bead pellets were washed three times with Tris-buffered saline, resuspended in loading buffer and analyzed by SDS-PAGE.

Pull-down assays for RhoA GTPase and Racl GTPase were performed respectively with glutathione agarose bound GST-Rhotekin-RBD pro- 
tein beads and GST-PAK-PBD protein beads (Cytoskeleton) according to protocols described previously (Vinot et al., 2008). The lysis buffer for RhoA GTPase pull-down assay consists of $50 \mathrm{~mm}$ Tris, pH 7.2, $500 \mathrm{~mm}$ $\mathrm{NaCl}, 1 \%$ Triton X-100, $0.5 \%$ sodium deoxycholate, $10 \mathrm{~mm} \mathrm{MgCl}_{2}$. The lysis buffer for Rac GTPase pull-down assay consists of 25 mM HEPES, pH 7.5, $100 \mathrm{~mm} \mathrm{NaCl}, 1 \%$ Nonidet P-40, $10 \mathrm{~mm} \mathrm{MgCl}_{2}$, 5\% glycerol, 5 $\mathrm{mm} \mathrm{NaF}, 1 \mathrm{~mm} \mathrm{NaOVa}$. Both buffers contain $1 \mathrm{~mm}$ phenylmethylsulfonyl fluoride and a mixture of protease inhibitors. Briefly, cleared cell lysates were incubated with the appropriate beads, then the beads were washed and suspended in $5 \times$ Laemmli loading buffer. The whole-cell lysate was also used to examine the total amount of Rho GTPase in the cells. Samples were analyzed by Western blotting with anti-RhoA and anti-Rac antibodies. Signal intensity was quantified using ImageJ.

Sample preparation and immunofluorescent staining. Cells were fixed in $4 \%$ paraformaldehyde (PFA) for $15 \mathrm{~min}$, permeabilized for $2 \mathrm{~min}$ in $0.1 \%$ Triton X-100 (unless nonpermeabilized cells were used, as indicated), rinsed in PBS, and blocked with $1 \mathrm{mg} / \mathrm{ml}$ bovine serum albumin (BSA). Samples were incubated with primary antibodies followed by the appropriate fluorochrome-labeled secondary antibodies. Actin was visualized by phalloidin-TRITC (Sigma) and nuclei were counterstained with Hoechst 33258 (Sigma). Mowiol mounting medium was used (Calbiochem).

Centrosome reorientation assay. Transfected cells were plated on coverslips and cultured until they reached confluence. Cell-free areas were generated by scratching the cell monolayer with a $1000 \mu \mathrm{ltip}$. After $0 \mathrm{~h}$, $4 \mathrm{~h}$, or $8 \mathrm{~h}$, cells were fixed with cold methanol for $5 \mathrm{~min}$, permeabilized 3 min with permeabilization buffer [20 mM HEPES, pH 7.5, $50 \mathrm{~mm} \mathrm{NaCl}$, $5 \%$ Triton X-100, $3 \mathrm{~mm} \mathrm{MgCl}_{2}, 300 \mathrm{~mm}$ sucrose], rinsed in PBS and blocked with PBS 2\% BSA. Nuclei were stained with Hoechst 33258 and centrosomes with anti- $\gamma$-tubulin. Cells were observed under the microscope using a $20 \times$ objective. Reorientation was assayed in the cells located at the wound edge and centrosome reorientation quantified as previously described (Etienne-Manneville, 2006). Briefly, four $90^{\circ}$ quadrants emanating from the center of the nucleus are generated so that the one facing the wound has a median perpendicular to the scratch. Polarized cells are defined as having their centrosome located in the quadrant facing the wound. Random orientation of the centrosome with respect to the wound edge corresponds to a value of $25 \%$. The percentage of polarized cells in each independent experiment was obtained with the average of duplicates, analyzing 100 cells in each duplicate. Data represent the mean \pm SEM from three independent experiments.

Morphological analysis and cluster analysis. Stable populations of Olineu cells expressing shRNA (shLuc or shNG2) or NG2del mutants (NG2del WT, NG2del T2256V, or NG2del T2256E) were either transfected with siRNA or were untransfected. Cells were trypsinized and seeded on coverslips in medium containing $0-20 \mathrm{ng} / \mathrm{ml} \mathrm{FGF}$. After $6 \mathrm{~h}$, cells were fixed and stained for nuclei and actin and observed with a $40 \times$ objective for morphological analysis and a $10 \times$ objective for cluster analysis. Nuclei staining was used to identify single cells and actin staining to outline the cell shape.

Morphological analysis was performed only with isolated cells, cell clusters were ignored in the quantification. The types of cell morphology were divided into six categories: cells without processes; cells with one, two, three, and four processes; or cells with more than four processes, branching being ignored. Cell processes were defined in a similar fashion to neurites: thick processes emerging from the cell body, and bearing thinner protrusions such as filopodia. Cells bearing only filopodia and/or lamella around the cell body were counted as cells without processes. The percentage of the different shapes was obtained by analyzing 80 cells in each independent experiment.

Cluster analysis was performed by counting the percentage of cells assuming clusters. Cells were considered in a cluster when the cell bodies (corresponding to perikaryon) of two different cells were in contact. When contact was only via cell processes, cells were considered isolated. The percentage of cells in clusters was obtained by analyzing 100 cells in each independent experiment. Data represent the mean \pm SEM from three independent experiments.

Cell migration assays. Migration of Oli-neu cells was performed with Boyden chambers ( $8 \mu \mathrm{m}$ pore size filter; BD Biosciences). The $2 \times 10^{5}$ cells were seeded in the upper chamber with $200 \mu \mathrm{l}$ of medium and the chamber was placed in 24 -well dishes. The bottom well contained $600 \mu \mathrm{l}$ of medium. In chemotaxis assays, only the medium in the bottom well contains bFGF whereas in chemokinesis assays bFGF is present on both sides of the filter. Migration was performed at $6 \mathrm{~h}$ and membranes were then fixed with $4 \%$ PFA. Non-migrated cells were removed from the top compartment with a cotton swab. Cells that had migrated to the lower side of the filter were stained with Hoechst 33258, photographed with an inverted microscope, and counted. Data are expressed as a percentage of basal migration, i.e., the migration of Oli-neu without chemoattractant.

Fluorescence resonance energy transfer experiments. Exponentially grown Oli-neu cells were infected with the retroviral vector pBabe-PuroRhoA Biosensor (Hodgson et al., 2010). After antibiotic selection, cells were transfected with either the control siRNA or the siRNA directed against NG2. One day after plating, cells were fixed with 4\% PFA for 15 min, stained for NG2 without permeabilization (revealed with a Cy5labeled secondary antibody), and mounted with Mowiol. Samples were imaged using a Leica TCS SP5 laser scanning confocal microscope and a $63 \times$ Plan Apochromat 1.4 NA oil objective. Cyan fluorescent protein (CFP) was excited using the $405 \mathrm{~nm}$ diode. The CFP and yellow fluorescent protein (YFP) emission channels were narrowed with a $460-505 \mathrm{~nm}$ and a 525-600 nm bandpass filter, respectively. Pinholes were opened to give a depth of focus of $200 \mathrm{~nm}$. Scanning was performed on a line-byline basis with the zoom level set to 3 . The gain for each channel was set to $\sim 75 \%$ of dynamic range (16 bits) and offsets set such that background was zero. Images were analyzed with MetaMorph Version 7.7.0.0. Briefly, images were smoothed using $3 \times 3$ median filter and background was substracted. The fluorescence resonance energy transfer (FRET) efficiency was calculated as the ratio YFP emission/CFP emission. The FRET efficiency is displayed as a pseudocolor thermal map on which blue corresponds to low efficiency and red to high efficiency: higher FRET efficiency corresponds to high levels of RhoA activity. The relative activity of RhoA at the cell periphery was quantified from the FRET efficiency ratio map. Two regions of $60 \mathrm{~nm}$ width were defined in the cell body (corresponding to perikaryon): the cortical region, corresponding to the most peripheral region in the cell, and the subcortical region, at a distant of 60 $\mathrm{nm}$ from the cortical region (see Fig. $5 B$ ). The intensity was measured inside $60 \mathrm{~nm}$ diameter circles in each region. Pairs of circles were drawn so that both were crossed in the middle by a line perpendicular with the membrane tangent. The cortical/subcortical intensity ratio was measured with the ratio of intensities measured inside these pairs of circles (Fig. $5 B$ ). The intensity ratio of single cells corresponds to the average of three ratios measured in randomly chosen areas. The cortical/subcortical intensity ratio in each independent experiment was obtained from an average ratio of 10 analyzed cells. Data represent the mean \pm SEM from three independent experiments.

In vivo experiments. Homozygous NG2-EYFP knock-in mice (Karram et al., 2008) and wild-type littermates at the age of 3 months of either sex underwent a stab wound as described previously (Dimou et al., 2008). Briefly, a 1-1.5 mm long/0.7 $\mathrm{mm}$ deep stab wound was made using a $\mathrm{V}$-lancet scalpel in the right sensorimotor cortex. Brains were examined $3 \mathrm{~d}$ after lesion. For histological analysis, animals were anesthetized and transcardially perfused with 4\% PFA. Brains were postfixed for $20 \mathrm{~min}$, cryoprotected in $30 \%$ sucrose, and stained according to standard protocols (Simon et al., 2011). The images were collected with a fluorescent microscope (Leica DM6000) or a laser scanning confocal microscope (Leica SP5). All animal procedures were performed in accordance with the policies of the use of Animals and Humans in Neuroscience Research, revised and approved by the Society of Neuroscience and the state of Bavaria under license numbers 55.2-1-54-2531-23/04 and 55.2-1-542532-171-11.

The quantification of polarized axes was performed by analyzing in the proximal region (50-300 $\mu \mathrm{m}$ from the wound) and the distal region (300-550 $\mu \mathrm{m}$ from the wound) the shape of OPC soma stained for PDGFR $\alpha$, which is expressed by OPC in both genotypes. Round or multipolar soma were counted as not polarized (round soma can correspond to cells elongated perpendicularly to the section, i.e., parallel to the wound). The orientation of elongated bipolar soma (with a major axis at least twice bigger than the minor axis) was marked with a line crossing the 
OPC soma on its longest dimension. Four $90^{\circ}$ quadrants joining in the center of the OPC soma divide the space so that the quadrant facing the wound is bisected by a line perpendicular to the wound. Cells are scored with a polarized axis when the line marking their orientation is positioned in the quadrant facing the wound. The percentage of potentially polarized cells among the total population of OPC soma was obtained by analyzing three distinct areas adjacent to the wound for each animal. Data represent the mean \pm SEM from four mice of each genotype.

The quantification of polarized OPC in the rostral migratory stream (RMS) was performed by analyzing brain sagittal sections of EYFP knock-in mice and wild-type littermates of either sex at the age of $15 \mathrm{~d}$. The analysis was identical to the stab wound analysis except that the four $90^{\circ}$ quadrants intersecting in the center of the OPC soma divide the space so that two opposite quadrants are bisected by a line parallel to the orientation of the RMS. Cells are scored with a polarized axis when the line marking their orientation is positioned in these two quadrants. The percentage of potentially polarized cells among the total population of OPC soma was obtained by analyzing 100 cells per slice in three distinct slices for each animal. Data represent the mean \pm SEM from four mice of each genotype.

Statistical analysis. Results were obtained from at least three independent experiments. Data are presented as mean \pm SEM. Comparisons between groups were analyzed by $t$ test. Significance was accepted for values where ${ }^{\star} p<0.05,{ }^{* *} p<0.01$, and ${ }^{* * *} p<0.001$.

\section{Results}

\section{NG2 regulates polarized migration of OPC}

We assayed the role of NG2 in polarity establishment during OPC migration with a centrosome reorientation assay (Fig. 1). Oli-neu cells (Jung et al., 1995), a widely used and well characterized cell line established in our group, were used as a model of OPC. They were transfected with siRNA against NG2, or syntenin, an accepted regulator of polarized migration (Sala-Valdés et al., 2012), resulting in decreased expression of these proteins (Fig. 1A). Application of a scratch in a confluent monolayer of cells induces migration of cells toward the wound. The relocalization of the centrosome in cells at the wound edge, shown by staining with $\gamma$-tubulin, is a read-out for polarized migration (EtienneManneville and Hall, 2001). Thus, polarized cells have their centrosome inside a $90^{\circ}$ quadrant facing the wound (Fig. $1 B, C$ ). At $0 \mathrm{~h}, \sim 25 \%$ of cells were polarized in all conditions, reflecting the random orientation of centrosomes. The percentage of polarized cells in untransfected conditions or transfected with the siRNA control increased at $4 \mathrm{~h}$ and reached $40 \%$ at $8 \mathrm{~h}$. In contrast, cells with NG2 siRNA or syntenin siRNA stagnated at $\sim 30 \%$ of polarized cells at 4 and $8 \mathrm{~h}$. The same effect was observed in primary OPC. Whereas $40 \%$ of primary OPC transfected with the siRNA control were polarized $4 \mathrm{~h}$ after the scratch, $<30 \%$ of cells transfected with NG2 siRNA were polarized (Fig. 1D). This result reveals that NG2 regulates the establishment of polarity in migrating cells.

To analyze OPC polarization in vivo, we made a stab wound in a cortical hemisphere of adult wild-type mice (WT) and also in mice lacking NG2 (NG2-/-; Karram et al., 2008). $\gamma$-Tubulin staining in the wound area had a high background, making it unsuitable for quantification of OPC polarity in vivo. We thus used cell morphology as a marker of polarization. After $3 \mathrm{~d}$, many OPC soma near the wound had acquired an elongated shape compatible with migration, in contrast to OPC somas observed in the contralateral hemisphere, which exhibited a round and multipolar shape. We identified cells with an elongated soma whose axis was orientated toward the wound to quantify the percentage of cells potentially polarized toward the lesion among the total population of OPC (Fig. 1E,F). We defined two regions: a border zone $50-300 \mu \mathrm{m}$ from the wound and a lateral zone $300-$ $550 \mu \mathrm{m}$ away. In the border zone of WT mice, $45 \%$ of OPC were polarized whereas in NG2 $-/-$ mice only $27 \%$ of OPC were polarized. Inversely, in the lateral zone, $28 \%$ of WT OPC exhibited a polarized axis in contrast to $46 \%$ of NG2-/- OPC. These results confirm that NG2 also regulates polarity of OPC in vivo and reveal that the percentages of polarized cells in WT and NG2 - / - mice depend on the location in the wound.

The wound resulted in an upregulation of GFAP in astrocytes in the border zone (Fig. 1G). We observed a gradient of bFGF staining in the entire lesioned hemisphere with the highest levels adjacent to the wound (Fig $1 H$ ). Reactive astrocytes have been reported to produce bFGF and could contribute to the establishment of a cytokine gradient next to the wound (do Carmo Cunha et al., 2007; Clemente et al., 2011). Indeed, staining for bFGF demonstrated that the level of bFGF appeared twice as high in the border zone as in the lateral zone. In the border zone, where the concentration of bFGF is high, WT OPC polarize toward the wound whereas OPC in NG2-l- mice fail to polarize. In the lateral zone where levels of bFGF are lower, WT OPC appear insensitive to the bFGF signal and fail to polarize whereas OPC in NG2-/- mice polarize in response to this weak stimulus. Basic FGF is an established chemoattractant and known to promote OPC migration (Zhang et al., 2004). These results thus suggest that bFGF and NG2 regulate migration via common signaling pathways and that NG2 differently regulates migration depending on the levels of cytokine.

To investigate if NG2 could regulate similarly the polarity of OPC during development, we studied the polarization of OPC in the RMS of P15 WT and NG2 -/- mice (Fig. 2). Cells from the subventricular zone migrate toward the olfactory bulb through the RMS and OPC have been reported to migrate through this pathway (Aguirre and Gallo, 2004). Immature neurons of the RMS were stained with DCX and OPC with PDGFR $\alpha$, facilitating their identification in both WT and NG2 - /- mice. We quantified the percentage of polarized OPC with an elongated soma whose axis was parallel to the RMS. However, we found no difference between WT and NG2-/- mice, in each case $\sim 37 \%$ of OPC exhibited a polarized morphology.

\section{NG2 regulates chemotaxis, chemokinesis, and cell shape}

To analyze how NG2 regulates polarity, we used transwell assays to monitor polarized migration induced by bFGF (Fig. 3A). Chemotaxis served as a mode of directed migration and chemokinesis reported random migration (see Material and Methods). We established Oli-neu cell lines stably expressing either a control shRNA directed against luciferase (shLuc), or an shRNA directed against NG2 (shNG2) (Fig. 3B). ShLuc Oli-neu cells were attracted by bFGF at 5 and $10 \mathrm{ng} / \mathrm{ml}$ in chemotaxis experiments (Fig. 3A, left). NG2 downregulation significantly inhibited bFGF-induced chemotaxis at $5 \mathrm{ng} / \mathrm{ml}$. We then analyzed chemokinesis in the presence of bFGF (Fig. 3A, right). ShLuc Oli-neu displayed no increased migration at 5 and $10 \mathrm{ng} / \mathrm{ml}$, but at $20 \mathrm{ng} / \mathrm{ml} 146 \%$ of the basal migration was seen. Inversely, in shNG2 Oli-neu, chemokinesis represented $117 \%$ of basal migration at $5 \mathrm{ng} / \mathrm{ml}$ and reached $168 \%$ at $10 \mathrm{ng} / \mathrm{ml}$, decreasing to $94 \%$ at $20 \mathrm{ng} / \mathrm{ml}$. Impairment of chemotaxis by NG2 downregulation confirmed the requirement of NG2 for polarized migration of OPC. In addition, the surprising effect of NG2 downregulation on chemokinesis revealed that NG2 has also an inhibitory effect on random migration, which is overcome only at high concentrations of cytokine (20 $\mathrm{ng} / \mathrm{ml}$ bFGF).

We analyzed the effect of NG2 downregulation on Oli-neu cell shape in the presence of bFGF by counting process numbers (Fig. 
A
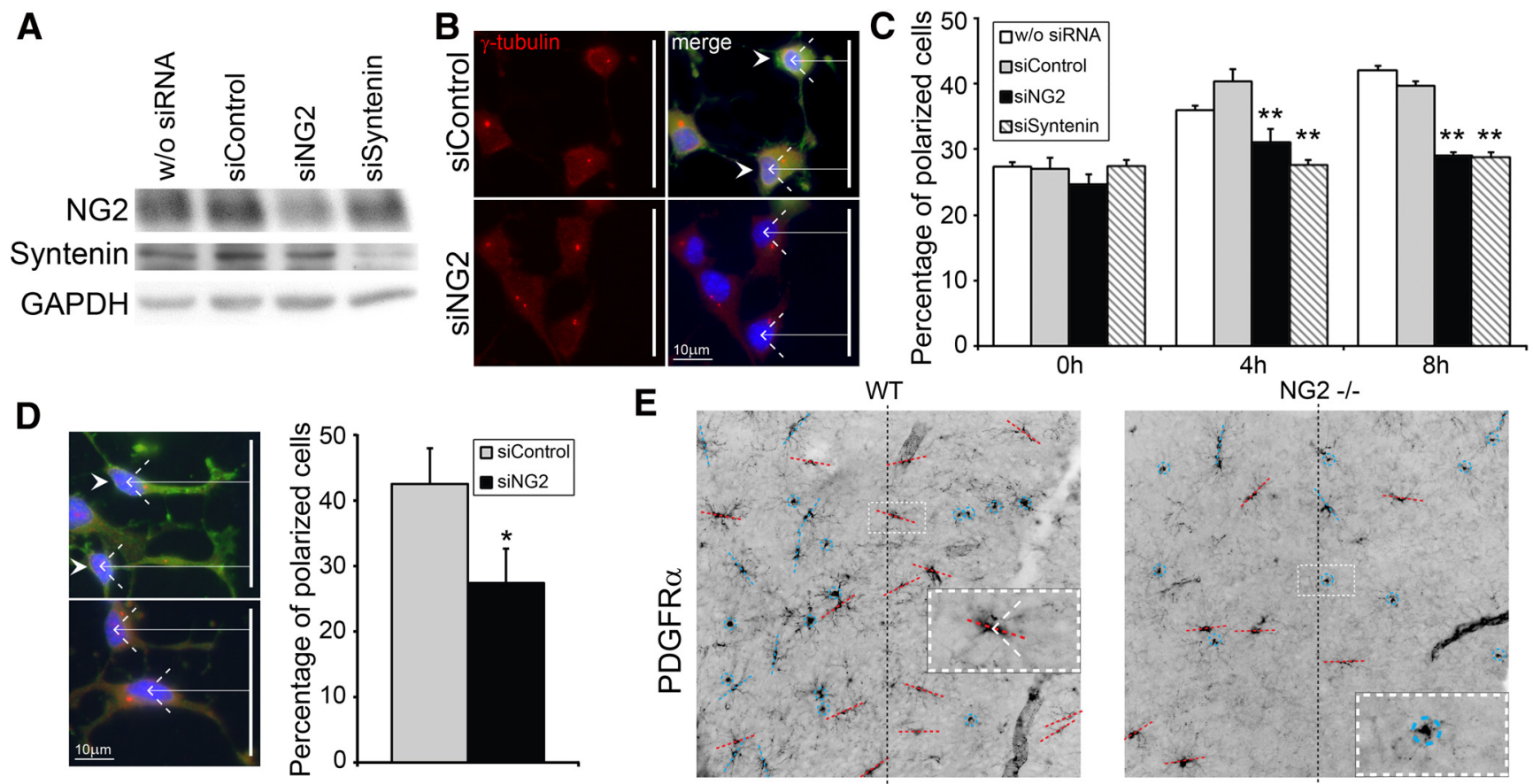

E
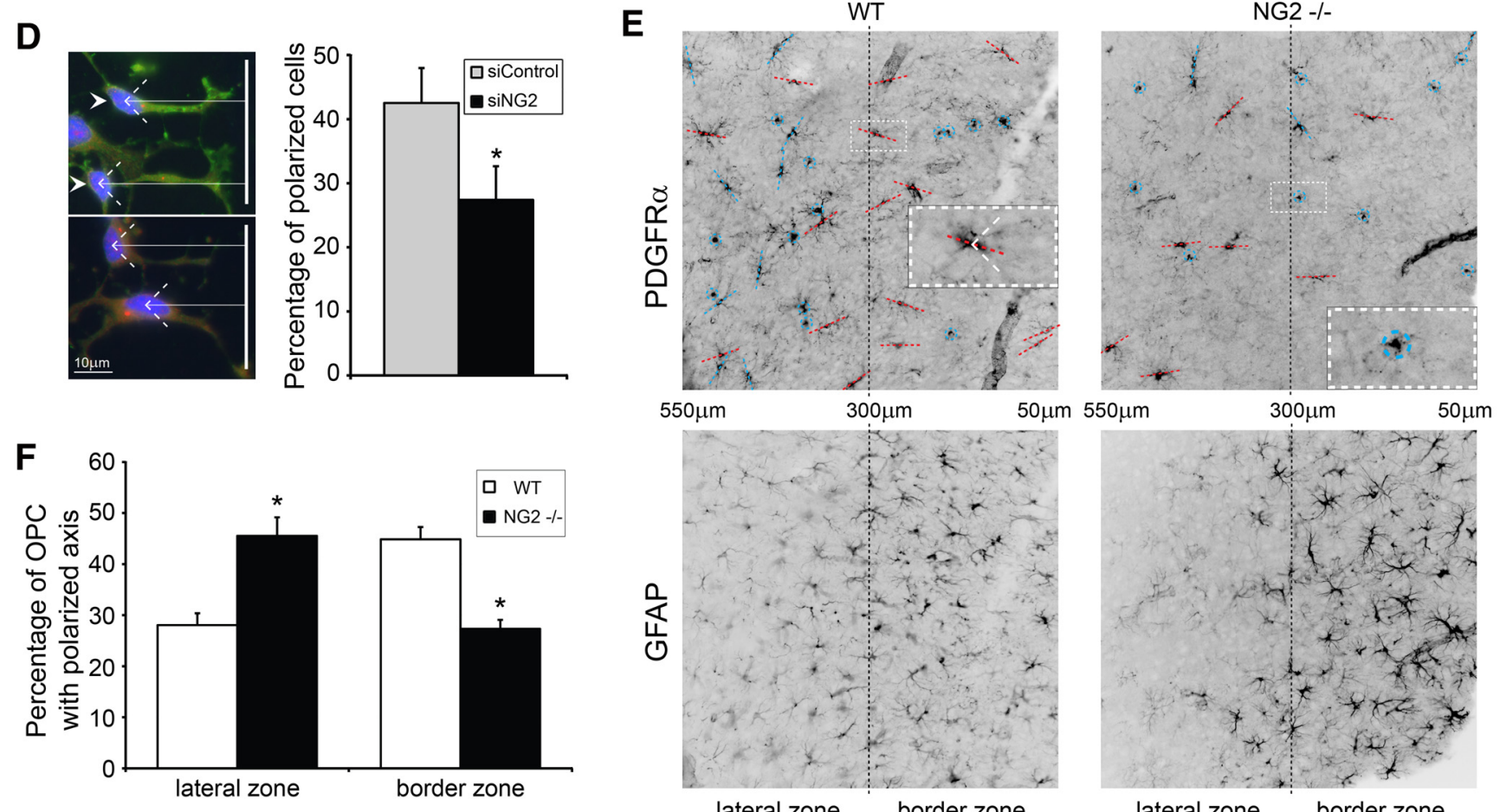

\section{G}
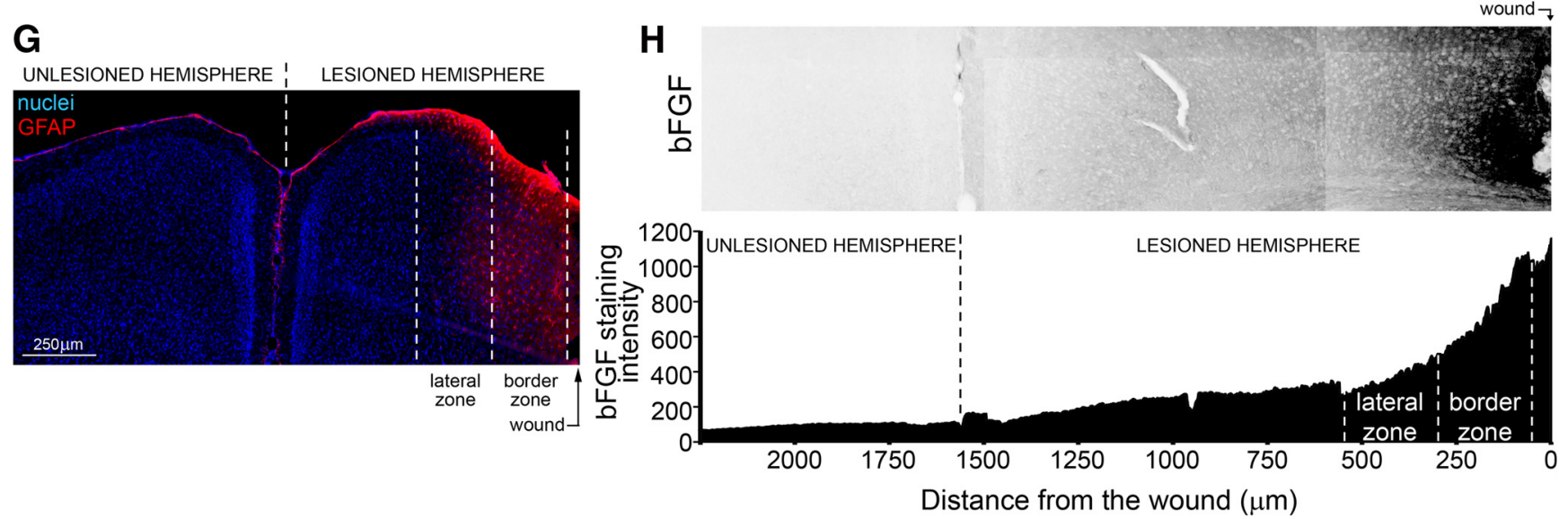

Figure 1. NG2 regulates polarized migration of OPC. $A-C$, Centrosome reorientation assays were performed on scratched monolayers of Oli-neu cells cultured without transfection or transfected with control siRNA, siRNA directed against NG2 (siNG2), or syntenin (siSyntenin). $\boldsymbol{A}$, The expression of NG2 and syntenin was assayed by immunoblotting, GAPDH serving as a loading control. $\boldsymbol{B}$, Hoechst (nuclei, blue), $\gamma$-tubulin (centrosome, red), and NG2 (green) staining of Oli-neu cells at the edge of the wound $4 \mathrm{~h}$ after the scratch. The localization of the scratch is indicated by the vertical white line. Polarized cells (arrowheads) have their centrosome inside a $90^{\circ}$ quadrant facing the wound. C, The percentage of polarized cells was measured 0,4 , and $8 \mathrm{~h}$ after the scratch. $\boldsymbol{D}$, Centrosome reorientation assays were performed with primary OPC transfected with control siRNA or NG2 siRNA. Staining of cells at the edge of the wound $(\boldsymbol{B})$ and quantification of polarized cells measured $4 \mathrm{~h}$ after the scratch are presented. $\boldsymbol{E}-\boldsymbol{H}$, Histological analysis $3 \mathrm{~d}$ after application of a stab wound in the cerebral cortex of adult WT and NG2 $-/-$ mice. $\boldsymbol{E}$, The wound is localized at the right side of the pictures. OPC were stained with PDGFR $\alpha$ and astrocytes with GFAP (staining in black). Elongated soma with polarized axes are marked with red lines (insert, left), other elongated soma with blue lines and nonelongated soma with blue circles (insert, right). $\boldsymbol{F}$, Quantification of the percentage of cells with polarized axes among the total population of OPC. Statistical significance was calculated relative to siControl or WT mice. G, Nuclei and GFAP staining in lesioned and unlesioned hemisphere. $\boldsymbol{H}$, bFGF staining (black) in lesioned and unlesioned hemisphere (top) and quantification of the signal intensity (bottom). 

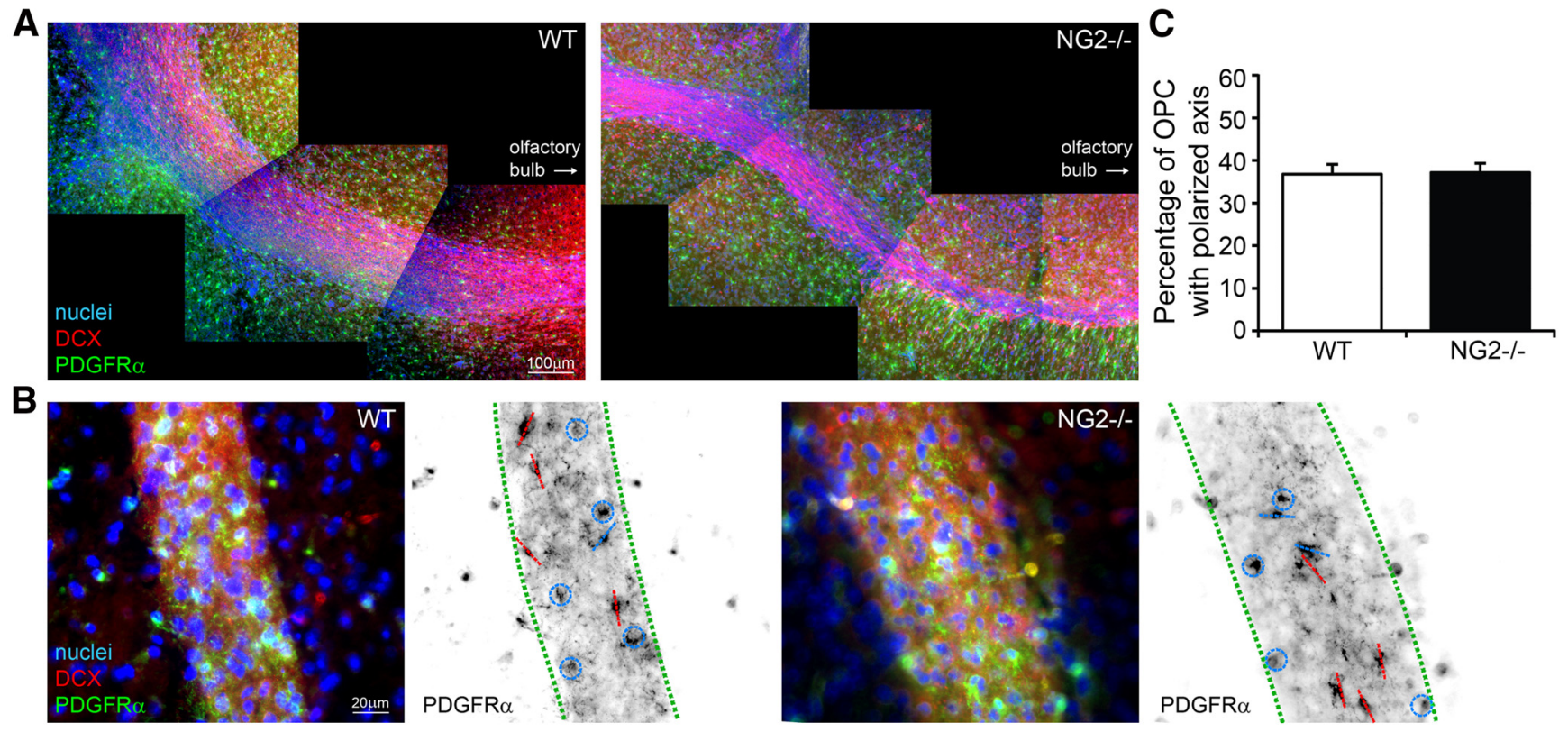

Figure 2. Quantification of polarized OPC in the RMS during development. $\boldsymbol{A}$, Histological analysis of the RMS of P15 WT and NG2 - / - mice. $\boldsymbol{B}$, Analysis of OPC orientation inside the RMS (RMS outlined with dotted green lines): elongated soma with polarized axes are marked with red lines, other elongated soma with blue lines and nonelongated soma with blue circles. $\boldsymbol{C}$, Quantification of the percentage of cells with polarized axes among the total population of OPC.

$3 C, D)$. Cell processes were defined as neurite-like processes emerging from the cell body. We did not observe nuclear staining typical of mitotic cells, excluding that the alteration of proliferation observed in OPC with NG2 knock-down in vivo (Kucharova and Stallcup, 2010) could indirectly affect process outgrowth over the time of our assay. In the absence of bFGF, Oli-neu expressing either shLuc or shNG2 presented identical profiles: the major population consisted of cells bearing two processes, representing, respectively, 32 and $28 \%$ of cells (Fig. $3 \mathrm{Ca}, \mathrm{Ce}, \mathrm{D}$ ). While bFGF treatment had no effect on the shape of shLuc Oli-neu, it altered the morphology of shNG2 Oli-neu (Fig. 3D, right). At 5 and $10 \mathrm{ng} / \mathrm{ml} \mathrm{bFGF}$, the major population of shNG2 Oli-neu, $27 \%$ of the cells, consisted of cells bearing three processes (Fig. $3 C f, C g)$. At $20 \mathrm{ng} / \mathrm{ml}$, cells without processes were the most abundant (38\%) (Fig. 3Ch). Thus NG2 inhibits bFGF-dependent process outgrowth. In shNG2 cells, the increased number of cell processes at 5 and $10 \mathrm{ng} / \mathrm{ml}$ bFGF correlates with random migration whereas the decreased number of cell processes at $20 \mathrm{ng} / \mathrm{ml}$ bFGF correlates with loss of random migration. It is thus likely that NG2 controls a signaling pathway regulating process outgrowth as well as migration.

\section{NG2 constitutively activates RhoA and inhibits Rac}

RhoA activity is known to limit process protrusion (Vega et al., 2011). Using a GTPase pull-down assay, we measured a fourfold decrease of RhoA activity in Oli-neu cells when NG2 was downregulated, showing that NG2 stimulates RhoA activity (Fig. $4 A, B)$. Concomitantly, Rac activity exhibited a 2.5 -fold increase (Fig. 4C), in support of the known inhibition of Rac by RhoA (Vega et al., 2011).

During oligodendrocyte differentiation, loss of NG2 parallels a decrease of RhoA activity and an increase of Rac activity (Liang et al., 2004). We therefore analyzed if the alteration of RhoGTPase activity was directly related to NG2 downregulation, or was indirect due to differentiation to mature cells. Oli-neu differentiation was induced with dbcAMP treatment (Jung et al., 1995) and was attested by PLP expression (Fig. 4D). The absence of PLP in cells after NG2 downregulation confirmed that the alteration of GTPase activity observed in the absence of dbcAMP was not a consequence of differentiation.

bFGF is a potent activator of Rac (Shin et al., 2002) and Rac stimulates both migration and process outgrowth (Ridley, 2001). In conditions of adhesion similar to the ones used for the morphological experiments and transwell assays, we observed that bFGF treatment induced a higher activity of Rac in shNG2 Oli-neu than in shLuc Oli-neu (Fig 4E, inserts and graph). This shift of Rac activity could thus explain the effect of bFGF on shNG2 Oli-neu morphology. Outgrowth activity was visualized by recruitment of ezrin, an ERM family protein that links Rac activation to changes in the actin cytoskeleton (Mackay et al., 1997; Auvinen et al., 2007; Binamé et al., 2008). Treatment with $10 \mathrm{ng} / \mathrm{ml}$ bFGF resulted in a strong labeling of cell processes only in cells expressing the shRNA directed against NG2 (Fig. 4E, arrowheads), suggesting that the increased Rac activity stimulated by bFGF in shNG2 Oli-neu is responsible for the induction of process outgrowth. Thus NG2 activates RhoA and reduces bFGF-induced Rac activation. In addition, all the conditions exhibiting a level of Rac activity higher than shLuc Oli-neu treated with 10 ng/ml bFGF (Fig $4 E$, graph) presented an elevated chemokinetic response (Fig $3 A$; with the exception of shNG2 with $20 \mathrm{ng} / \mathrm{ml}$ bFGF, probably because process outgrowth is inhibited here), arguing for a central role of Rac in the migration behavior observed.

\section{ROCK inhibition reproduces the effects of NG2 downregulation on migration}

RhoA limits the number of cell protrusions through ROCKmediated suppression of Rac activity (Vega et al., 2011). ROCK inhibition in OPC has already been reported to induce process protrusion (Siebert and Osterhout, 2011) but was not sufficient to induce differentiation (Czopka et al., 2009). Similarly, we observed that ROCK inhibition in Oli-neu cells induced multiple process protrusion, with $30 \%$ of the cells bearing $>4$ processes ( $\mathrm{F}$. Binamé, unpublished observation), but without altering NG2 expression (Fig. 4F). In bFGF-induced chemotaxis, shLuc Oli-neu migration increased $50 \%$ over basal level (migration without che- 
A

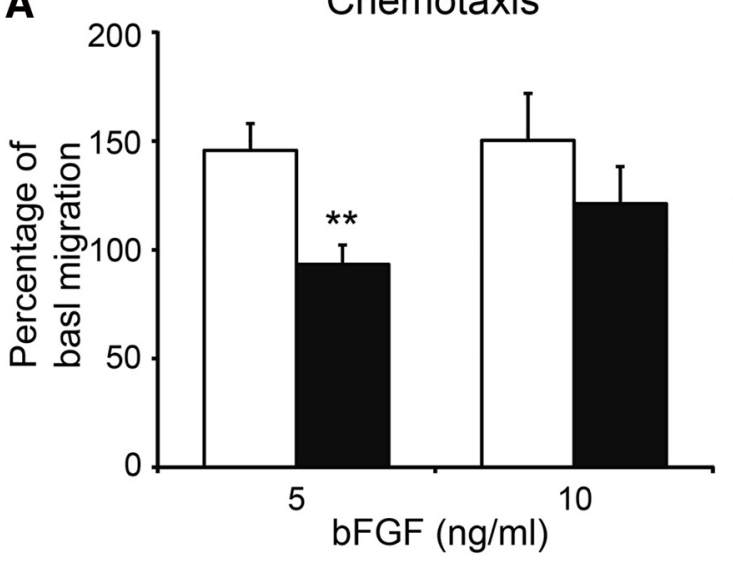

B

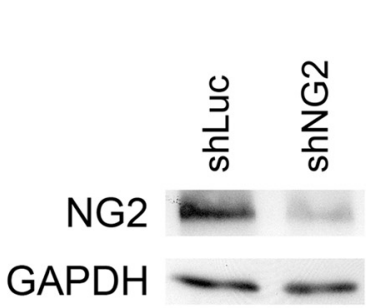

C bFGF:

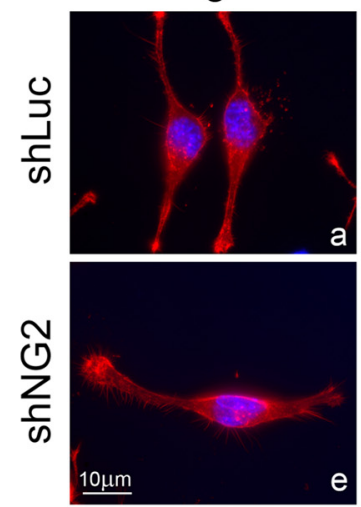

shLuc

D

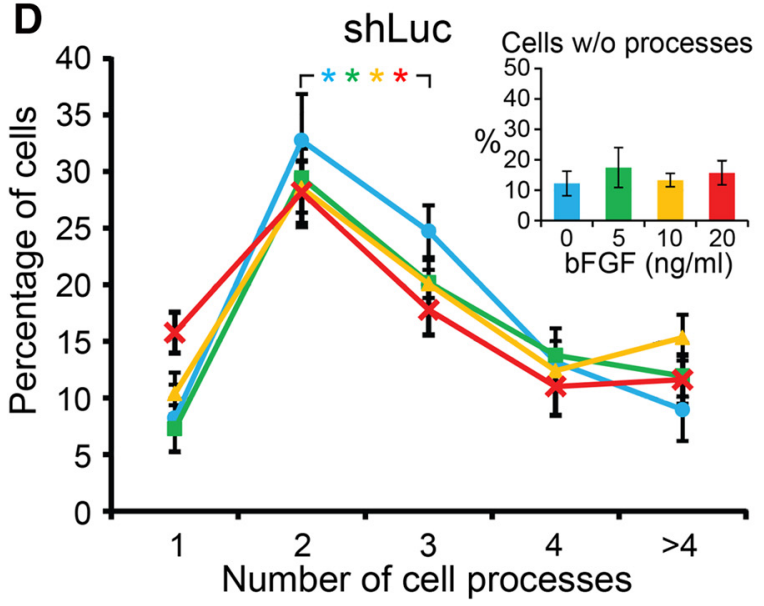

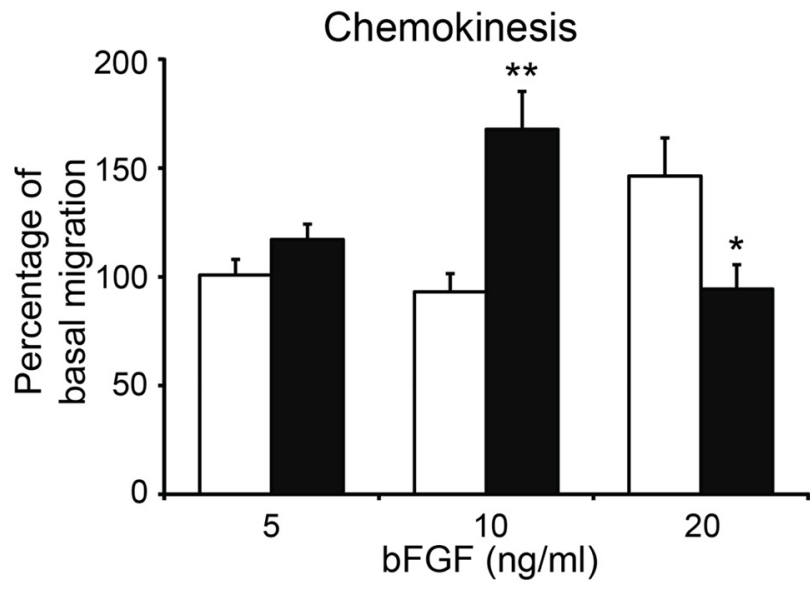

$5 \mathrm{ng} / \mathrm{ml}$

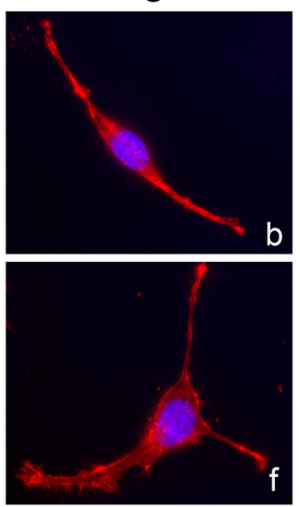

$10 \mathrm{ng} / \mathrm{ml}$
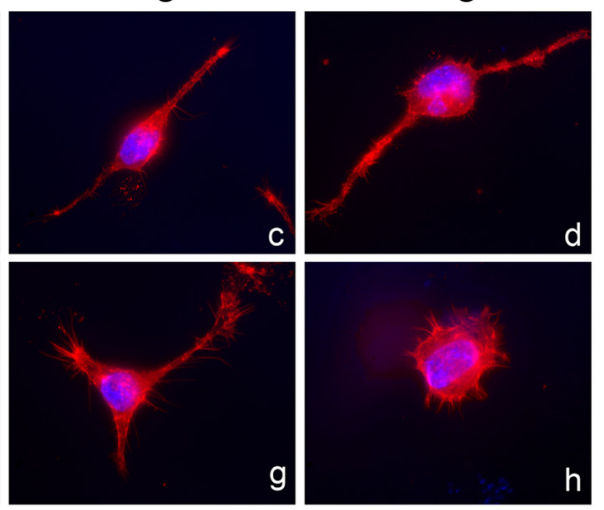

shNG2

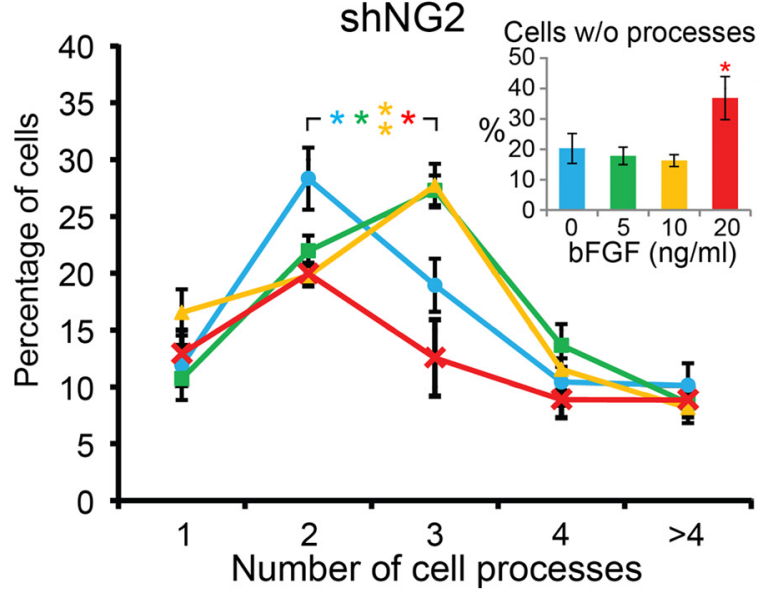

Figure 3. NG2 regulates chemotaxis and preserves the bipolar shape of OPC in bFGF-induced migration. Oli-neu cells, stably expressing either the control (shLuc) or the NG2-directed (shNG2) shRNA, were used for migration assays $(\boldsymbol{A})$ and morphological analysis $(\boldsymbol{C}, \boldsymbol{D})$. $\boldsymbol{A}$, Transfilter chemotaxis (left) and chemokinesis (right) of Oli-neu in response to bFGF. Results are expressed as a percentage of basal migration, i.e., migration without chemoattractant. Statistical significance was calculated relative to shLuc. $\boldsymbol{B}$, NG2 and GAPDH (loading control) expressions were assayed by immunoblotting. C, D, Oli-neu cells expressing shLuc or shNG2 were plated on coverslips and incubated for $6 \mathrm{~h}$ with the indicated concentrations of bFGF, fixed, and stained for nuclei (Hoechst; blue) and actin (phalloidin; red) for morphological analysis. C, Representative images of the majority shape of Oli-neu cells in each condition. $\boldsymbol{D}$, Percentage of cells bearing $1,2,3,4$, or $>4$ processes and percentage of cells without processes (insert). Statistical significance was calculated between two and three processes with the same treatment and relative to $0 \mathrm{ng} / \mathrm{ml} \mathrm{bFGF}$ for cells without processes (insert). Data represent the mean \pm SEM from four independent experiments.

moattractant) but in the presence of ROCK inhibitors migration was reduced to $<100 \%$, similar to the results observed with downregulation of NG2 (Fig. 4G, left). Similarly, shLuc Oli-neu cells displayed no chemokinetic response to bFGF in the absence of inhibitors, whereas ROCK inhibition brought their migration to $130 \%$ of basal migration, close to the level obtained with shNG2 cells (Fig. 4G, right). Moreover, the ROCK inhibition had no effect on migration of shNG2 Oli-neu under these conditions.
These results support the concept that NG2 regulates bFGFdependent migration via the RhoA/ROCK pathway.

NG2 stimulates RhoA at the cell periphery and inhibits clustering of OPC

RhoA is located in the cytosol and at the plasma membrane (Adamson et al., 1992; Dietrich et al., 2009). Since NG2 is predominantly at the plasma membrane, we analyzed if the stimulation of 
A

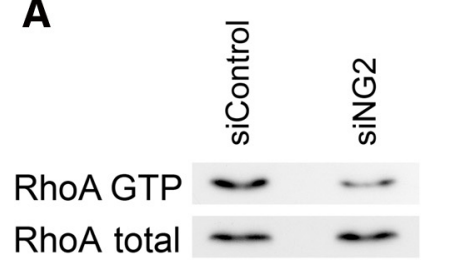

D

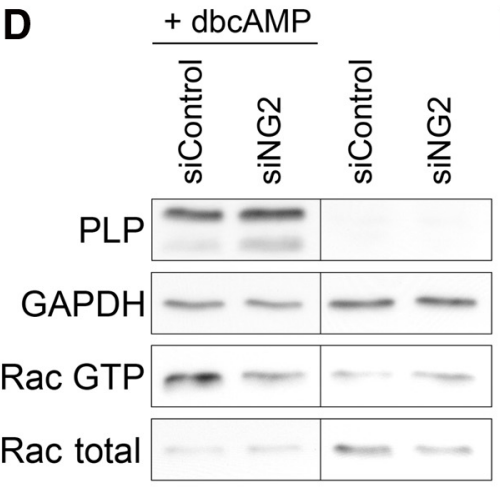

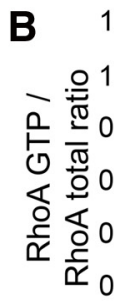

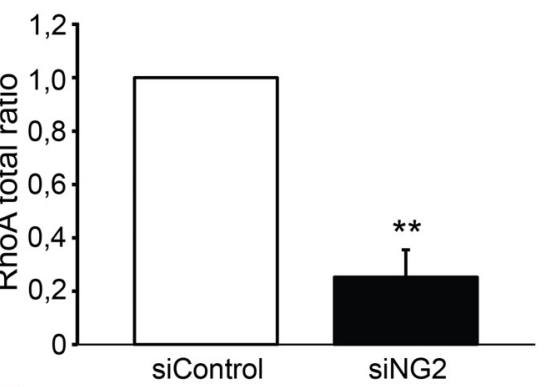

E

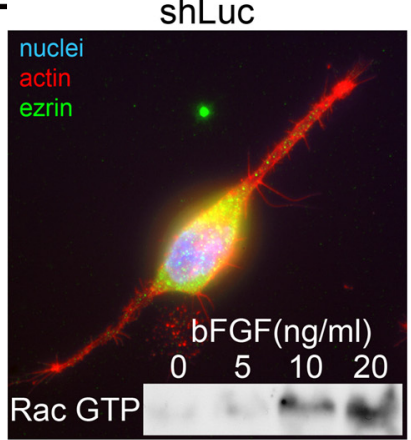

G
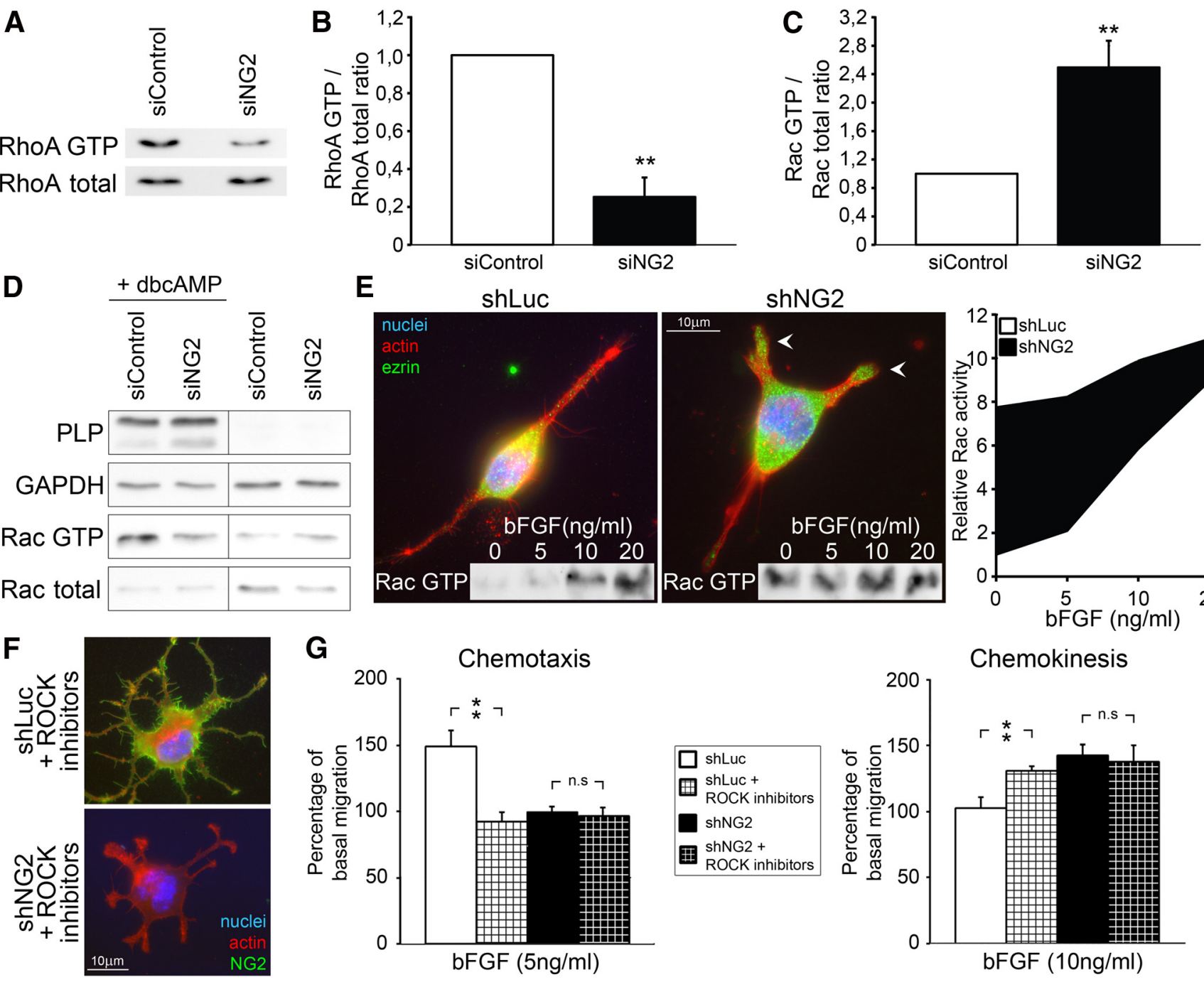

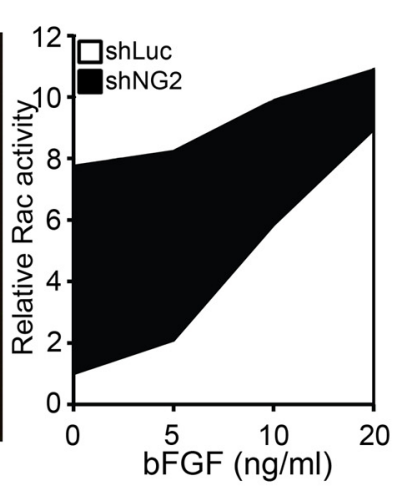

Chemokinesis
shNG2
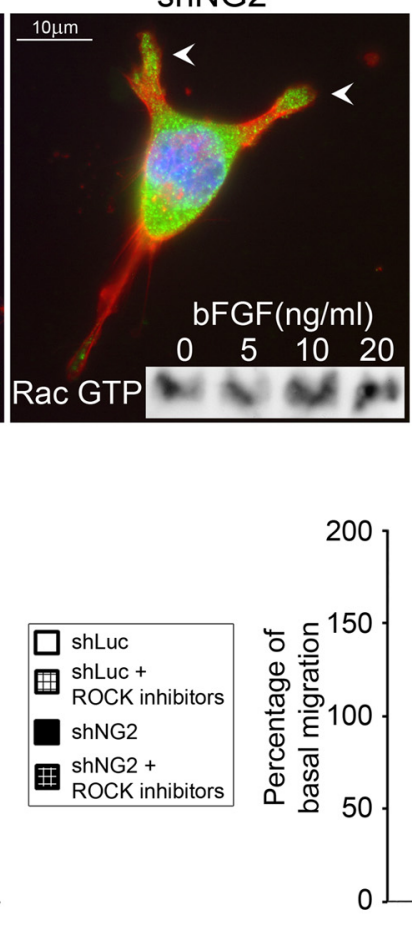

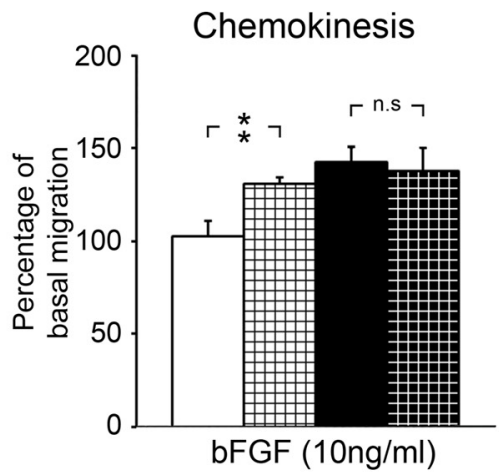

Figure 4. NG2 regulates migration of OPC by stimulating RhoA activity. $A-D$, RhoGTPase activity was assayed by GTPase pull-down assays in migrating Oli-neu cells transfected with control siRNA or siRNA directed against NG2. $\boldsymbol{A}, \boldsymbol{B}$, Western blot analysis $(\boldsymbol{A})$ and quantification of RhoA GTP/RhoA total ratio $(\boldsymbol{B})$. C, Quantification of Rac activity. $\boldsymbol{D}$, Oli-neu cells, either grown normally or differentiated with dbcAMP, were used to visualize Rac activity by immunoblotting. PLP was used as a differentiation marker. $\boldsymbol{E}-\mathbf{G}$, Oli-neu cells, stably expressing either the control (shLuc) or the NG2-directed (shNG2) shRNA, were used for immunofluorescence staining, biochemical analysis, and migration assays. E, Cells were plated on coverslips and treated $4 \mathrm{~h}$ with $10 \mathrm{ng} / \mathrm{ml} \mathrm{bFGF}$, then fixed and stained for nuclei, actin, and ezrin. $\boldsymbol{E}$, inserts and graph, Rac activity was assayed by GTPase pull-down assays in cells treated $3 \mathrm{~h}$ with the indicated concentration of bFGF immediately after plating. $F$, Cells were plated on coverslips and treated $6 \mathrm{~h}$ with ROCK inhibitors, then fixed and stained for nuclei, actin, and NG2. G, Transfilter chemotaxis (left) and chemokinesis (right) in response to bFGF with or without ROCK inhibitors. Data represent the mean \pm SEM from three independent experiments (n.s., nonsignificant).

RhoA by NG2 was achieved at the cell periphery rather than in the cytosol. Oli-neu cells stably expressing a RhoA biosensor (Hodgson et al., 2010) were transfected with either a siRNA control or a siRNA directed against NG2. In cells with control siRNA, the FRET map revealed a $60-80 \mathrm{~nm}$ region of RhoA activity outlining the cell periphery, which was higher than the activity measured in the cell body center (Fig. 5A). When NG2 was downregulated, RhoA activity still appeared higher at the periphery but this difference was reduced (Fig. $5 A$ ). The ratio of the relative cortical/subcortical intensity of RhoA activity showed that RhoA activity was 3.3-fold higher at the cell cortex than in subcortical region in control cells, whereas after NG2 downregulation it was only 1.5-fold higher at the cell cortex (Fig. 5B). Thus, NG2 appears to stimulate RhoA selectively in the cell periphery.

The activity of the RhoA/ROCK pathway at the contact area between two cells has been shown to control contact inhibition of locomotion (CIL), a phenomenon that initiates a change in mi- gration direction when two cells contact one another (CarmonaFontaine et al., 2008). Oli-neu cells in culture grow as isolated cells in contrast to epithelial cells, which grow in islets. We postulated that NG2-dependent RhoA activity at the cell periphery could be responsible for cell spacing via a CIL-related phenomenon. In Oli-neu cells expressing the shRNA control, $<20 \%$ of the population were in clusters, independent of the presence of bFGF in the medium (Fig 5C). ShNG2 Oli-neu had, respectively, 34 and $40 \%$ of cells in clusters without or with bFGF. With ROCK inhibition, $>50 \%$ of the cells were in clusters, confirming the role of the RhoA/ROCK pathway in cluster inhibition. These results demonstrate that NG2 inhibits OPC clustering, in accordance with its stimulation of the RhoA/ROCK pathway at the cell periphery. As in CIL, control cells exhibited a strong RhoA activity at the contact between two cells (Fig. 5D). On the contrary, cells with NG2 downregulation exhibited no increase of RhoA activity at the cell-cell contact site, which would explain their propensity to form clusters. 
A
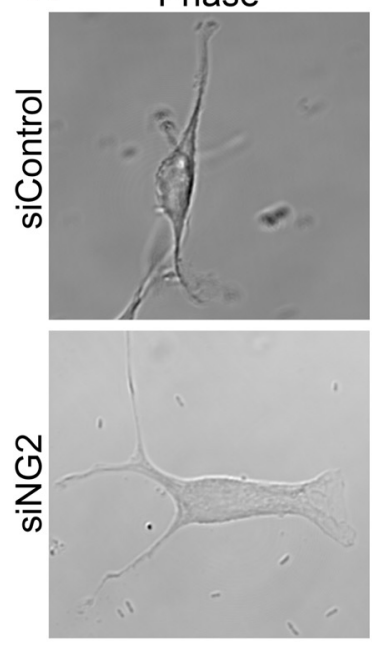

C

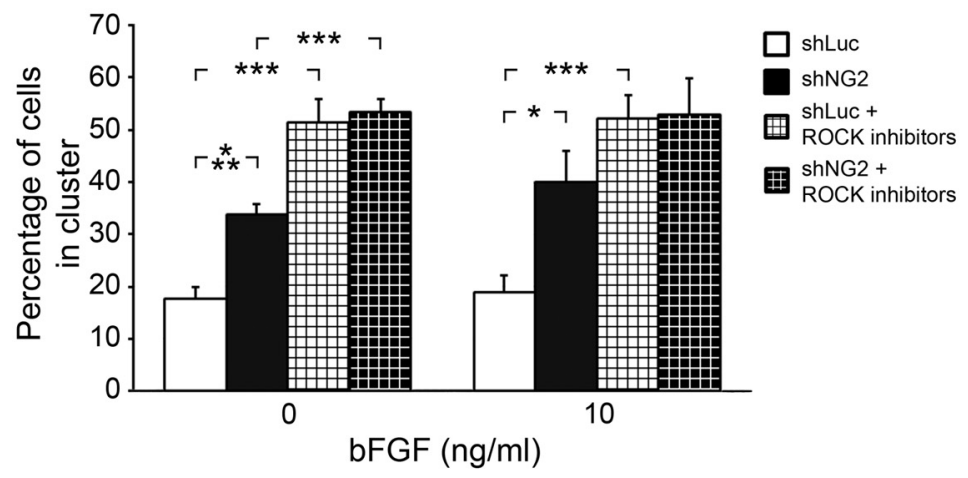

NG2
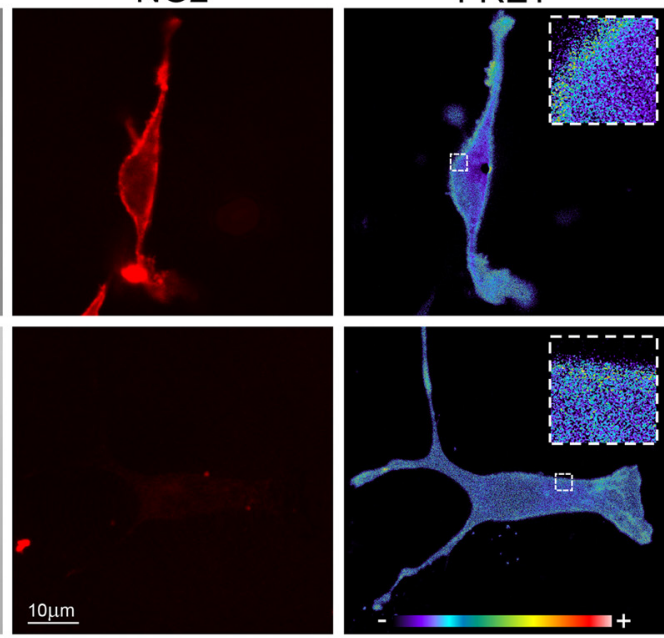

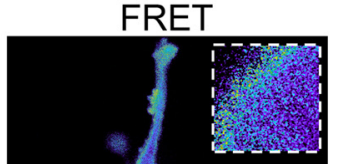

B
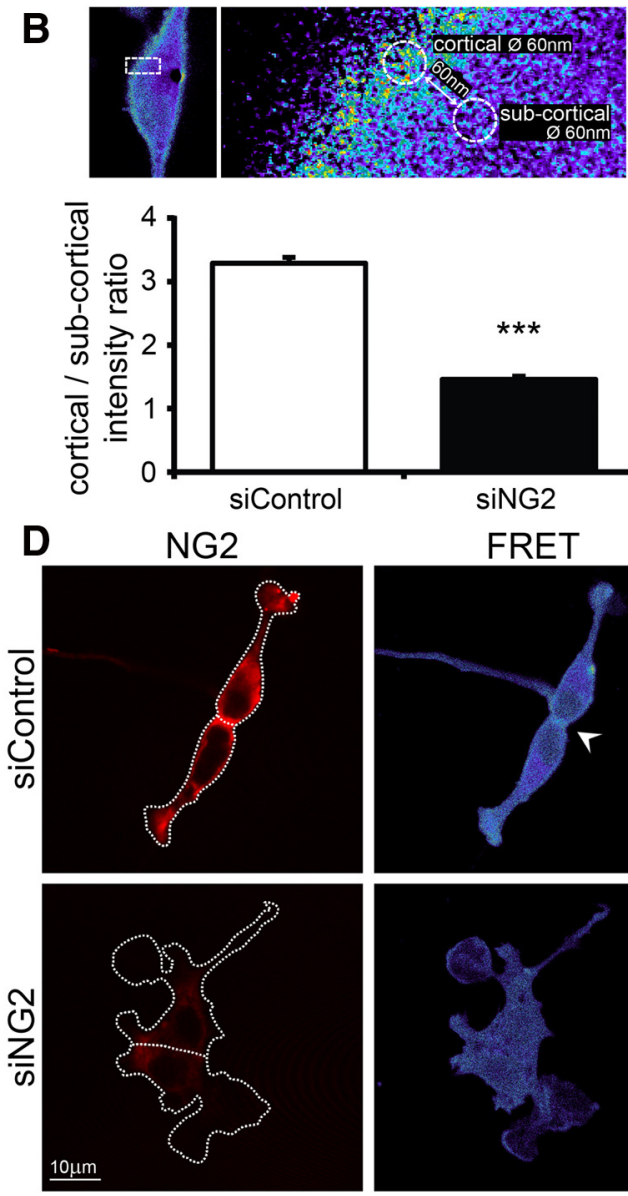

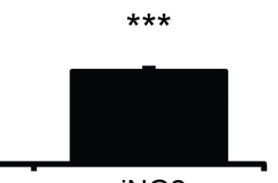

siNG2
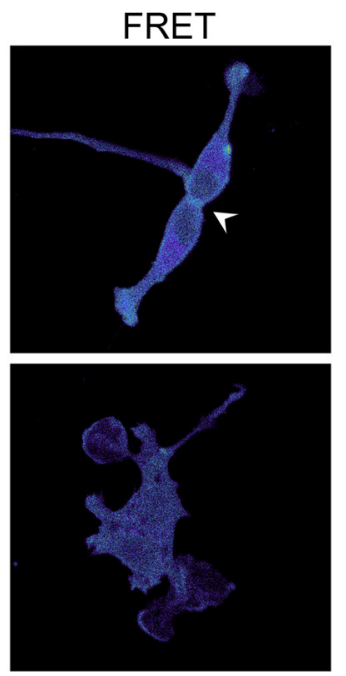

Figure 5. NG2 stimulates RhoA at the cell periphery and inhibits clustering of $O P C . A, B, D, O l i-n e u$ cells, stably expressing the pBabe-Puro-RhoA Biosensor, were either transfected with siControl or siNG2 and used for FRET analysis of RhoA activity. $A$, Single cell pictures of phase contrast (left), NG2 immunostaining (middle), and FRET analyzed by confocal microscopy. Inserts show an enlargement of FRET images. FRET efficiency is displayed as a thermal map so that "cold" and "warm" colors represent regions of low and high activity, respectively (scale at bottom). B, Quantification of the relative cortical/subcortical intensity ratio of RhoA activity in the cell body (regions depicted in the enlargement of the white square, top). $C$, Percentage of shLuc and shNG2 Oli-neu in cluster $6 \mathrm{~h}$ after plating and treatment with bFGF and/or ROCK inhibitors. D, NG2 immunostaining without permeabilization (cell outline shown with a dotted line) and FRET images of pairs of 0li-neu cells in contact. Cells transfected with siControl exhibit a strong RhoA activity at the cell contact area (arrowhead).

\section{NG2 activates RhoA through MUPP1/Syx1}

We analyzed a potential role of the polarity complex proteins MUPP1, PATJ, and the GEF Syx1 (Liu and Horowitz, 2006) in NG2 signaling. We transfected Oli-neu cells, either expressing shLuc or shNG2, with specific siRNAs directed against the above proteins, incubated them with $10 \mathrm{ng} / \mathrm{ml} \mathrm{FGF}$, and analyzed their shape (Fig. 6A). The efficiency of the siRNAs was validated by immunoblotting (Fig. 6B).

Oli-neu cells transfected with the siRNA control served as a reference. As previously reported, bFGF treatment did not affect the shape of shLuc Oli-neu with siControl (Fig. 6A, top right) while it changed the shape of shNG2 Oli-neu, switching the bipolar shape to three processes (Fig. $6 \mathrm{~A}$, bottom right). In the presence of bFGF, $40 \%$ of shLuc Oli-neu were bipolar whereas in shNG2 Oli-neu only $20 \%$ of cells had a bipolar shape. Thus, half of the bipolar cells became multipolar and hence unpolarized in this condition, supporting the role of NG2 in cell polarity. The dominant shape of shLuc Oli-neu treated with bFGF switched to cells with three processes when MUPP1 or Syx 1 were downregulated, whereas downregulation of PATJ (Fig. 6A, top right) had no effect. Moreover, no morphological modification was observed with any siRNA in the absence of bFGF, indicating that the observed results were specific for bFGF treatment (Fig. 6A, left). In shNG2 Oli-neu treated with bFGF, in all conditions the dom- inant shape consisted of cells with three processes, even with siMUPP1 or siSyx1, suggesting that MUPP1 and Syx1 are affecting the same signaling pathway as NG2. Downregulation of the GEF $\beta$-PIX abolished the effect of bFGF on shNG2 Oli-neu morphology (Fig. $6 C$ ), in accordance with the role of $\beta$-PIX in bFGFstimulated neurite outgrowth (Shin et al., 2002).

Since MUPP1 and Syx 1 modulated cell morphology in a similar way to NG2, we postulated that they could trigger NG2dependent stimulation of RhoA activity. GTPase pull-down assays suggested that downregulation of MUPP1 or Syx1 leads to decreased RhoA activity similar to that seen with NG2 downregulation (Fig. 6D).

We transfected Oli-neu cells with NG2 Flag-tagged expression vectors and precipitated NG2 constructs with anti-Flag antibodies, a NG2del WT construct without Flag but with a myc tag serving as a negative control (Fig. 6E).Three-fourths of the extracellular domain of NG2 is missing in NG2del and NG2trunk constructs and the PDZ-binding motif is deleted in NG2trunk. Two bands reacted with the Flag antibody: the higher band corresponding to the expected size of $65 \mathrm{kDa}$ and the lower to a cleaved form of $55 \mathrm{kDa}$. On the basis of the predicted extracellular juxtamembrane cleavage site in NG2 (Nishiyama et al., 1995; Stallcup and Huang, 2008), we concluded that the small band corresponds to the Flag-tagged extracellular domain of NG2del. 


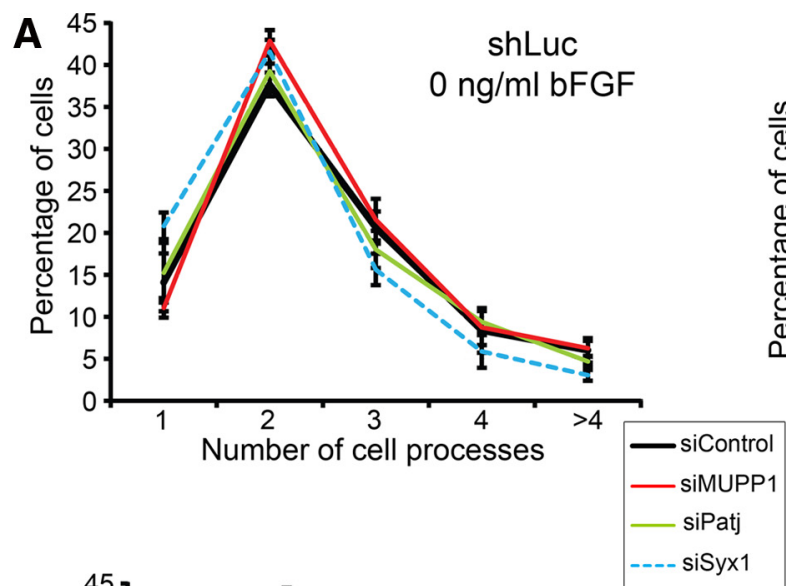

shLuc
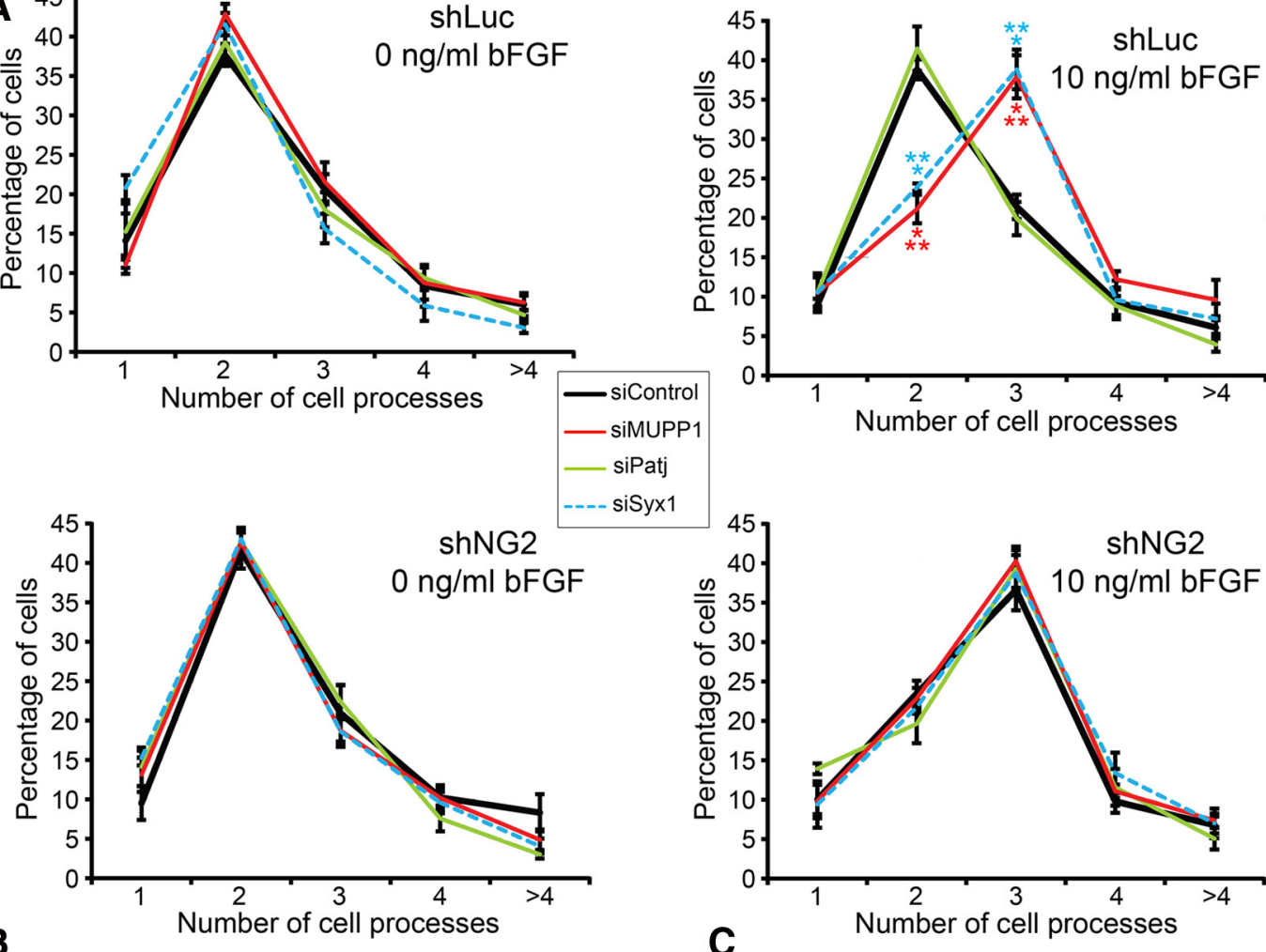

B

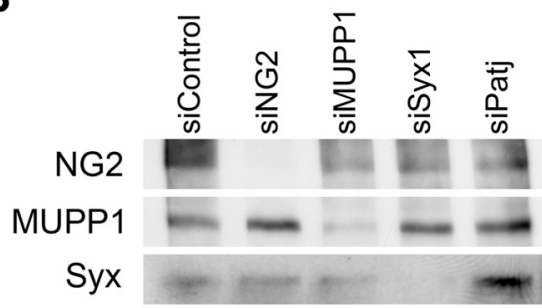

PATJ

GAPDH

D

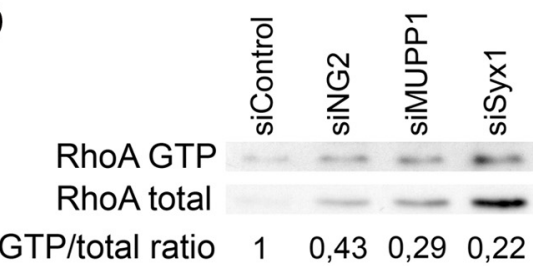

E
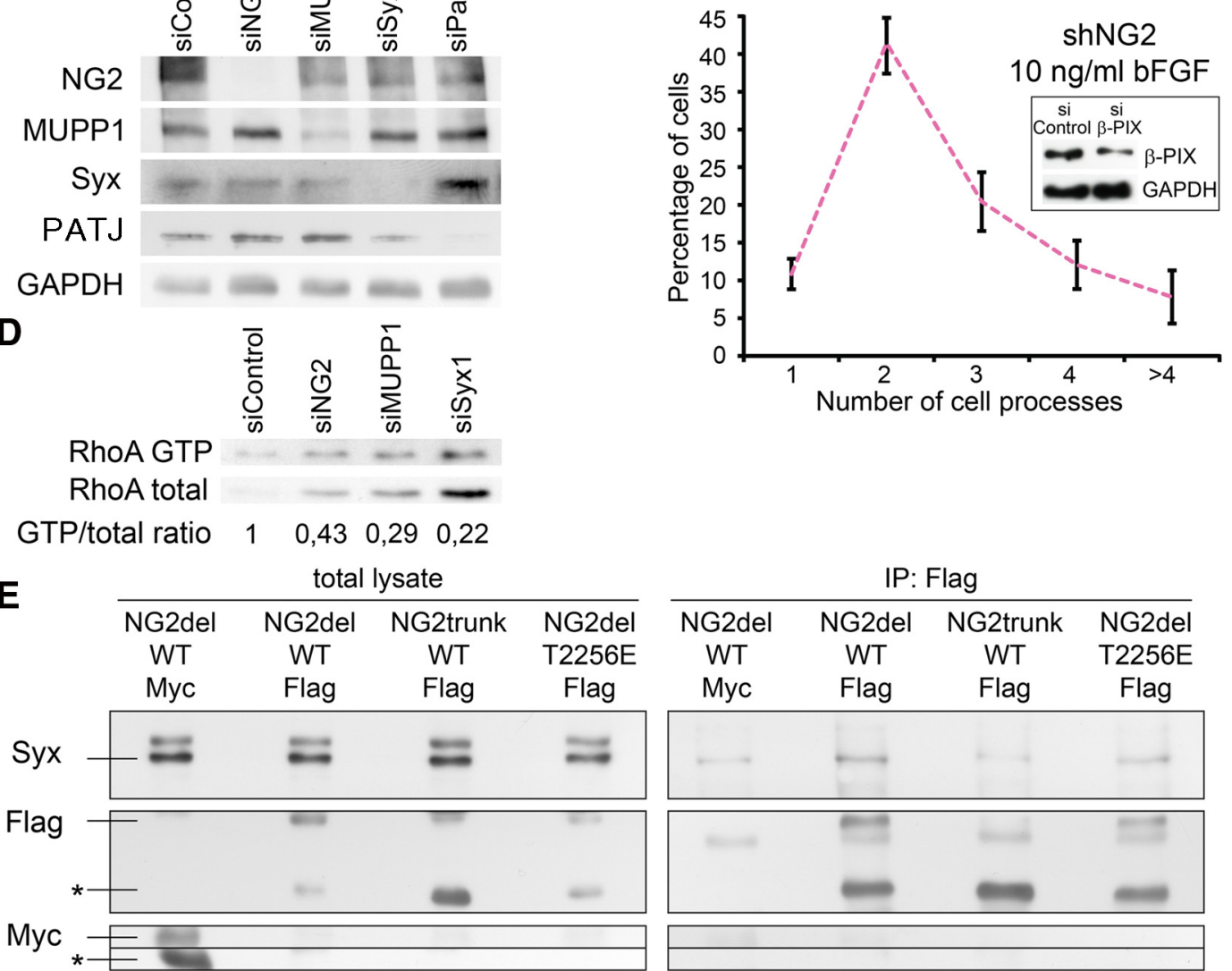

Figure 6. NG2 activates RhoA through MUPP1/Syx1. A, Oli-neu cells, stably expressing shLuc (top) or shNG2 (bottom), were transfected with indicated siRNA, plated on coverslips $6 \mathrm{~h}$ without bFGF (left) or in presence of $10 \mathrm{ng} / \mathrm{ml} \mathrm{bFGF}$ (right), then used for morphological analysis. The percentage of cells bearing 1,2,3,4, or $>4$ processes was calculated. Data represent the mean \pm SEM from four independent experiments. Statistical significance was calculated relative to siControl. $\boldsymbol{B}$, The downregulation of NG2, MUPP1, Syx1, and PATJ proteins in 0li-neu cells was controlled by immunoblotting. C, ShNG2 Oli-neu transfected with siRNA against $\beta$-PIX were plated on coverslips $6 \mathrm{~h}$ in presence of $10 \mathrm{ng} / \mathrm{ml} \mathrm{bFGF}$ and used for morphological (Figure legend continues.) 
The PDZ-binding motif deletion of NG2trunk WT increased this cleavage, possibly due to its implication in NG2 stability, which made interaction studies difficult. After immunoprecipitation of NG2del WT Flag, the Syx signal was stronger than the background observed in the negative control and with NG2trunk WT. With the phosphomimetic NG2del-T2256E Flag, the Syx signal appeared stronger than in the negative control but weaker than with NG2del WT. These results suggest that Syx may coimmunoprecipitate preferentially with NG2 when Thr-2256 is not phosphorylated.

\section{The phosphorylation of NG2 at Thr-2256 stimulates Rac, process outgrowth, and migration}

The Thr-2256-phosphorylated form of NG2 was localized in lamellipodia and stimulated migration (Makagiansar et al., 2004, 2007), processes known to be regulated by Rac. We thus postulated that phosphorylation of Thr-2256 would change downstream signaling of NG2 and could be responsible for stimulation of Rac activity. We thus used the NG2del-T2256E construct, which mimics threonine phosphorylation by glutamate substitution. NG2del WT and NG2del-T2256V, with a valine substitution that cannot be phosphorylated, served as negative controls. In a Rac GTPase pull down, Oli-neu cells constitutively expressing NG2del-T2256E showed a clear increase of Rac activity compared with NG2del WT and NG2del-T2256V (Fig. 7A). With all three constructs ezrin staining was observed in the cell body (Fig. $7 B$ ). However, while the total amount of ezrin revealed by immunoblotting was similar with the three constructs (Fig. 7A), cells expressing NG2del-T2256E exhibited a stronger ezrin staining in their processes independent of the number of cell processes. To study whether the localization of the NG2 phosphomutant in OPC was different from the nonphosphorylated form we performed immunostainings against the Flag-tag of the NG2del constructs. NG2delWT was localized at the membrane all around the cell body and in the cell processes similar to endogenous NG2 (Figs. 5A, 7C). On the contrary, NG2del-T2256E was preferentially localized in the cell processes. In primary OPC transfected with NG2del constructs, similar results were observed (Fig. 7D). Indeed NG2del WT was localized in the cell body as well as in the processes whereas NG2del-T2256E preferentially localized in the cell processes. Moreover, in addition to staining inside the cell body, ezrin staining was observed preferentially in cell processes containing NG2del-T2256E. These results argue for a recruitment of ezrin by the NG2 phosphomutant in cell processes.

We analyzed the effect of the NG2del constructs on Oli-neu migration in transwell assays (Fig. 7E). No significant differences in bFGF-dependent chemotaxis were observed between cells expressing the different NG2 constructs (Fig. 7E, left). However, we observed a strong effect of NG2del-T2256E on bFGF-dependent chemokinesis, where random cell migration increased to $182 \%$ of basal levels (Fig. $7 E$, right). The localization as well as the effect of NG2del-T2256E on Rac and ezrin suggested a process outgrowth promoting activity. Cells expressing NG2del WT and NG2del T2256V were bipolar as a majority shape, independent of the presence of bFGF (Fig. $7 B, F$ ). On the contrary, Oli-neu cells

\section{$\leftarrow$}

(Figure legend continued.) analysis. $\beta$-PIX and GAPDH expressions were assayed by immunoblotting (insert). $\boldsymbol{D}$, RhoA activity was assayed by GTPase pull-down assay in migrating Olineu cells transfected with indicated siRNA. $\boldsymbol{E}$, Migrating Oli-neu cells transfected with the indicated NG2 Flag- and Myc-tagged constructs were used to perform immunoprecipitations with anti-Flag beads. * indicates the cleaved form of NG2 protein. expressing NG2del-T2256E exhibited a more flattened profile. In comparison with the NG2del WT profile, we found significantly less cells with two processes and more cells with $>4$ processes independent of bFGF treatment (Fig. $7 B, F$ ). The multipolar shape induced by NG2del-T2256E favors random migration, thus explaining the enhancement of chemokinesis rather than chemotaxis induced by this construct. Importantly, it appears that phosphorylation of NG2 on Thr-2256 induces process outgrowth independent of bFGF treatment.

\section{NG2 activates Rac through recruitment of polarity complex proteins}

We subsequently looked for transducers of NG2del-T2256E signaling, postulating that their downregulation (Fig. $8 A-D$ ) would abolish the effect of the NG2 mutant on the cell shape. We performed morphological analysis on Oli-neu cells stably expressing NG2del-T2256E and transfected with siRNA directed against potential targets (Fig. 8A-C). The profile of the cells transfected with the siRNA control, with $25-27 \%$ of bipolar cells and $15-16 \%$ of cells with $>4$ processes, served as a reference. Downregulation of PATJ and Pals1, two components of the CRB polarity complex, restored the usual Oli-neu bipolar morphology: significantly more cells had two processes and fewer cells had $>4$ processes (Fig. 8A, left). Downregulation of Par3, a protein of the PAR polarity complex, gave identical results (Fig. $8 A$, right). Then, we studied the role of two GEFs stimulating Rac: $\beta$-PIX and Tiam 1 , which is recruited by the PAR complex and is known to regulate neurite outgrowth (Matsuo et al., 2003; Nishimura et al., 2005). Downregulation of $\beta$-PIX had no effect on cell morphology whereas downregulation of Tiam1 abolished the effect of NG2del-T2256E observed with the siRNA control, the cell population with two processes increasing and the one with $>4$ processes decreasing (Fig 8A, right).

Downregulation of Dlg1, a component of the SCRIB polarity complex, had no effect on cell morphology whereas the downregulation of other components of the $\mathrm{CRB}$ and PAR complexes (Crb2 and Par6, respectively) restored the bipolar morphology of Oli-neu, confirming that these polarity complexes were necessary to mediate the effect of the NG2 phosphomutant (Fig. $8 B$ ). Additionally, we tested the effect of MUPP1 and Syx1 downregulation, both implied in RhoA activation, on the morphology changes induced by NG2del-T2256E. Unexpectedly, MUPP1 and Syx 1 downregulation abolished the effect of NG2del-T2256E, restoring the bipolar shape as a majority shape (Fig. 8C). Downregulation of the RhoA effector Dial had the same effect, indicating that the RhoA signaling pathway collaborates with the polarity complexes to induce process outgrowth (Fig. 8B).

Since Rac stimulation via the polarity complex proteins could explain the process outgrowth induced by NG2del-T2256E, we measured by GTPase pull down the modulation of Rac activity (Fig. $8 D, E$ ) associated with downregulation of Tiam1, PATJ, and MUPP1. When transfected with siRNA control, cells expressing the NG2 phosphomutant displayed a strong Rac activity as previously shown. In contrast, Rac activity of cells expressing NG2del WT was 2.5 times lower. In cells expressing NG2delT2256E, downregulation of Tiam 1 and PATJ reduced Rac activity to the level observed in cells expressing NG2del WT. NG2del WT Oli-neu transfected with siTiam 1 showed no decrease of Rac activity compared with the same cells transfected with siRNA control, confirming that the effect of Tiam1 was specific for NG2del-T2256E. The fact that MUPP1 had no effect on NG2delT2256E-dependent Rac activation (Fig. 8E) was consistent with our results restricting its action to RhoA stimulation. 
A
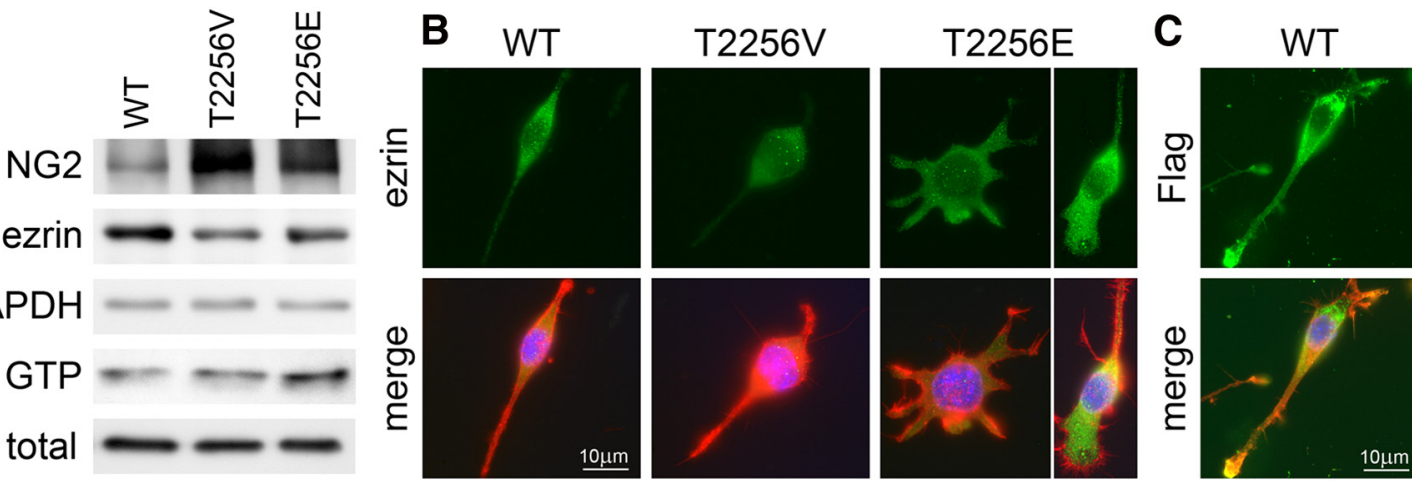

T2256E

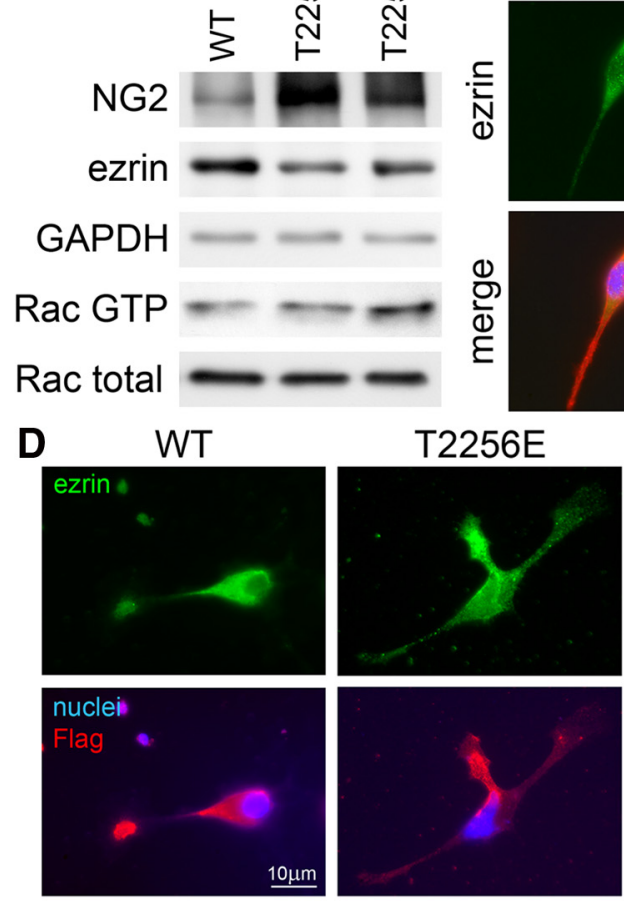

E

Chemotaxis
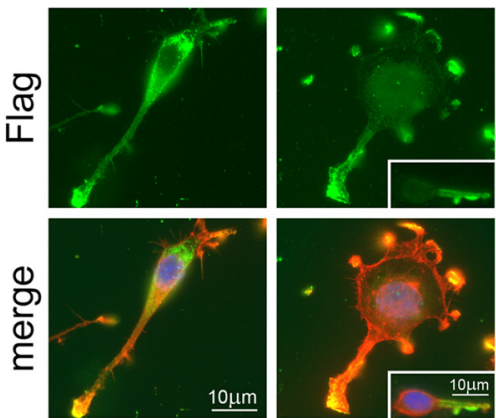

Chemokinesis

$\mathbf{F}$
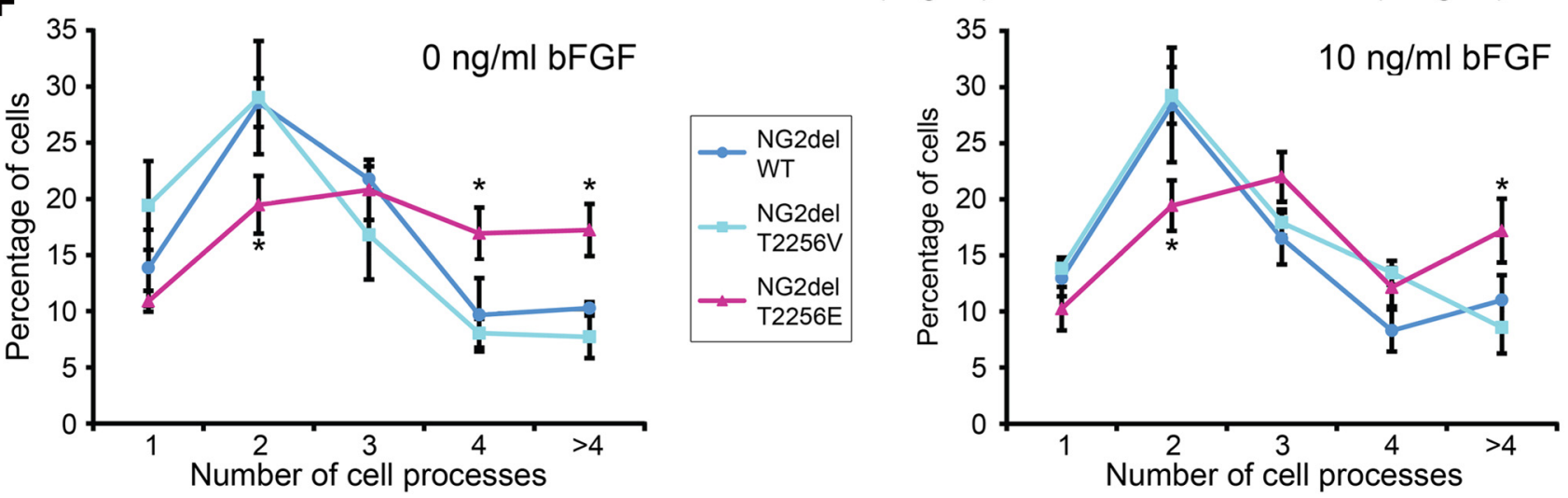

Figure 7. The phosphorylation of NG2 at Thr-2256 stimulates Rac, process outgrowth, and migration. Oli-neu cells, stably expressing NG2del WT, NG2del-T2256V, or NG2del-T2256E, were used to assay Rac GTPase activity $(\boldsymbol{A})$, for migration assays $(\boldsymbol{E})$, and for morphological analysis $(\boldsymbol{F})$. $\boldsymbol{A}$, Migrating cells were used to visualize Rac activity by immunoblotting. NG2, ezrin, and GAPDH expressions are shown. $\boldsymbol{B}, \boldsymbol{C}$, Cells were plated on coverslips, fixed $6 \mathrm{~h}$ later, and stained for nuclei (Hoechst; blue), actin (phalloidin; red), ezrin (green) (B), and NG2del Flag tag (green) (C). D, Primary OPC transfected with indicated NG2delconstructs were stained for ezrin, nuclei, and NG2del Flag tag. E, Transfilter chemotaxis (left) and chemokinesis (right) of Oli-neu in response to bFGF. Results are expressed as a percentage of basal migration, i.e., the migration of Oli-neu without chemoattractant. $F$, Cells were plated on coverslips $6 \mathrm{~h}$ without bFGF (left) or in presence of $10 \mathrm{ng} / \mathrm{ml} \mathrm{bFGF}$ (right), then used for morphological analysis. The percentage of cells bearing 1,2,3, 4, or $>4$ processes was calculated. Data represent the mean \pm SEM from four independent experiments. Statistical significance was calculated relative to NG2del WT.

We transfected Oli-neu cells with the Flag-tagged constructs NG2del WT and NG2del-T2256E and immunoprecipitated these constructs with beads bearing anti-Flag antibodies (Fig. $8 F$ ). In cells expressing the phosphomutant of NG2, more Pals1 was precipitated than in cells without transfection or expressing NG2del WT, pointing to the recruitment of Pals1 in a protein complex associated with the phosphorylated form of NG2. This result corroborates the requirement of PATJ and Pals1 to trigger the effect of the NG2 phosphomutant and introduces the CRB polarity complex as a new component of NG2 signaling.

\section{Discussion}

NG2 regulates polarized migration of OPC through activation of the RhoA/ROCK pathway

Here we demonstrate that NG2 controls polarity in OPC since NG2 downregulation prevented centrosome relocalization to- ward the leading edge, a characteristic of the front-rear polarity established during directional migration. NG2 downregulation also impaired bFGF-dependent chemotaxis, a behavior characterized by directional migration. ROCK inhibition reproduced the effect of NG2 downregulation: it inhibited chemotaxis and stimulated chemokinesis at $10 \mathrm{ng} / \mathrm{ml}$ bFGF. Moreover, ROCK inhibition had no effect on migration of shNG2 Oli-neu. These results suggest that the regulation of bFGF-dependent migration by NG2 is mainly mediated by ROCK. Therefore, the constitutive stimulation of RhoA activity by NG2 appears to favor polarized migration of OPC.

NG2 modulates the response of OPC to bFGF by inhibiting Rac

Rho GTPases are essential to establish the rear-front polarity of migrating cells (Etienne-Manneville and Hall, 2001). The asym- 

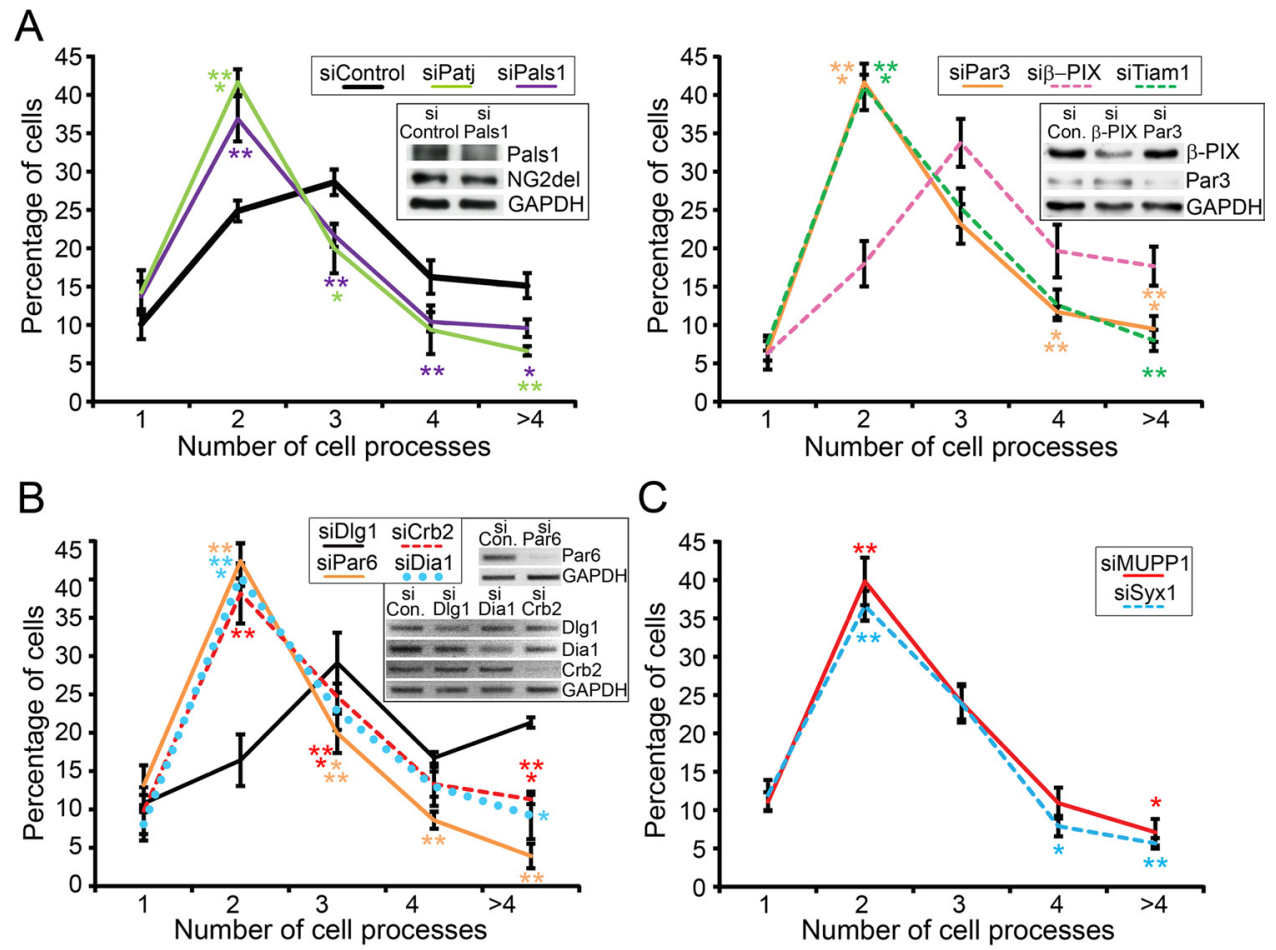

C
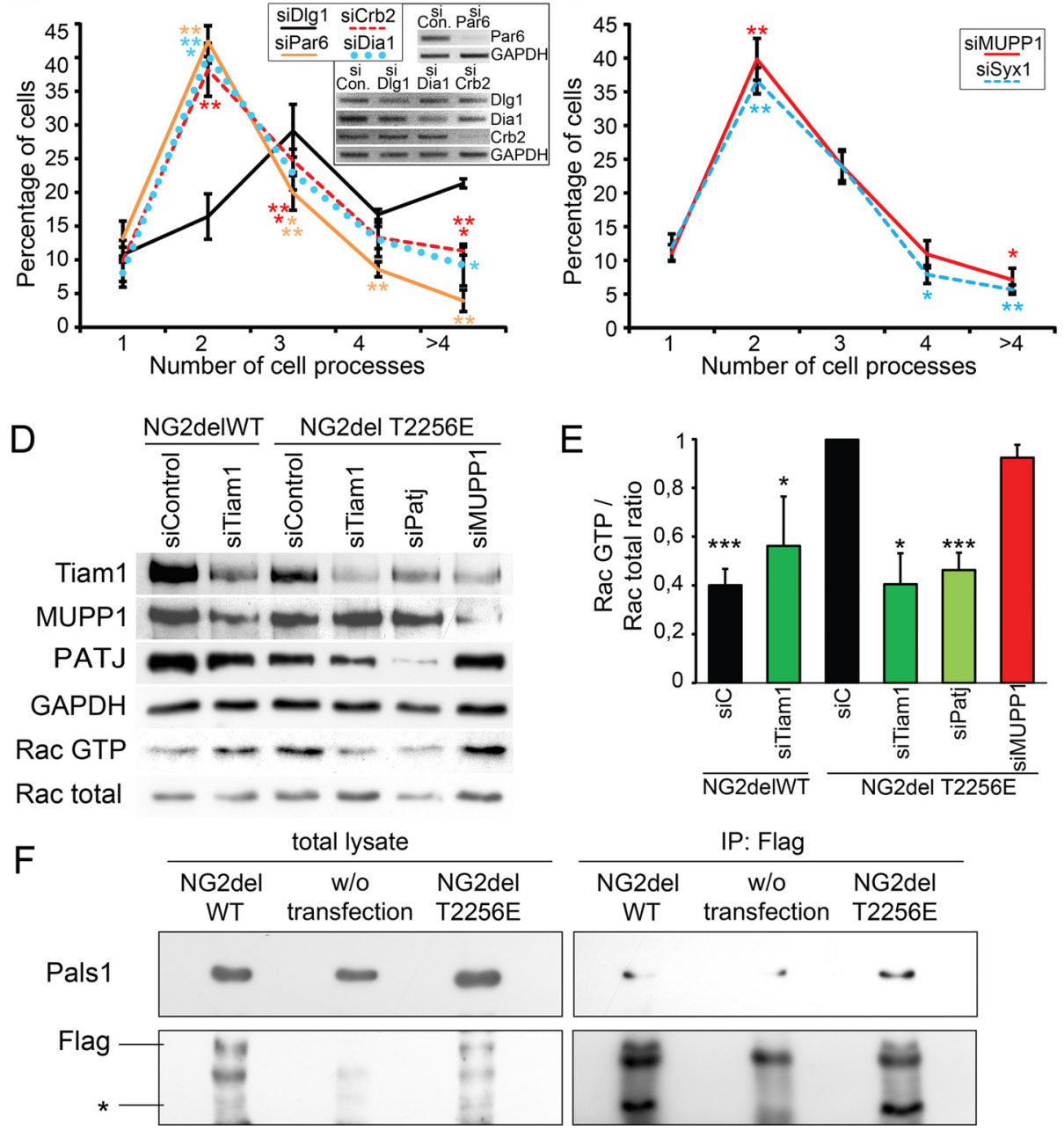

Figure 8. NG2 activates Rac through polarity complex proteins. A-C, Oli-neu cells, stably expressing NG2del-T2256E, were transfected with indicated siRNA, plated on coverslips $6 \mathrm{~h}$ without bFGF, and used for morphological analysis. The percentage of cells bearing 1, 2, 3, 4, or $>4$ processes was calculated. $\boldsymbol{A}$, inserts, Western blot analysis of Pals1, NG2del (anti-Flag) (left), $\beta$-PIX, Par3 (right), and GAPDH. B, insert, Expression of indicated mRNA, GAPDH being used as a control. D, E, Migrating Oli-neu cells, stably expressing either NG2del WT or NG2del T2256E and transfected with indicated siRNA, were used for Rac GTPase pull down. Western blot analysis of Tiam1, PATJ, MUPP1, GAPDH, and Rac (D) and quantification of Rac GTP/Rac total ratio (E). $\boldsymbol{F}$, Migrating 0li-neu cells without transfection, transfected with Flag-tagged NG2del WT or NG2del T2256E constructs, were used to perform immunoprecipitations with anti-Flag beads. * indicates the cleaved form of NG2 protein. Data represent the mean \pm SEM from four independent experiments. Statistical significance was calculated relative to Oli-neu cells stably expressing NG2del-T2256E and transfected with siControl.

metry observed in directional migration is characterized by a segregation of signaling pathways having opposing effects on protrusive forces. Thus the leading edge and more generally process formation relies on Rac activity, which promotes actin polymerization, whereas the rear of the cell is characterized by RhoA activity inhibiting protrusive forces via the ROCK pathway. We demonstrated that NG2 constitutively activates RhoA in OPC and leads to Rac inhibition, most likely via the RhoA/ROCK pathway (Yamaguchi et al., 2001). The release of this inhibition when NG2 is downregulated would thus explain the stronger activation of Rac induced by bFGF treatment, resulting in increased membrane activity revealed by the presence of ezrin in the cell processes.

While most Oli-neu cells are bipolar in the conditions studied, bFGF treatment of shNG2 Oli-neu modified the number of cell 
A

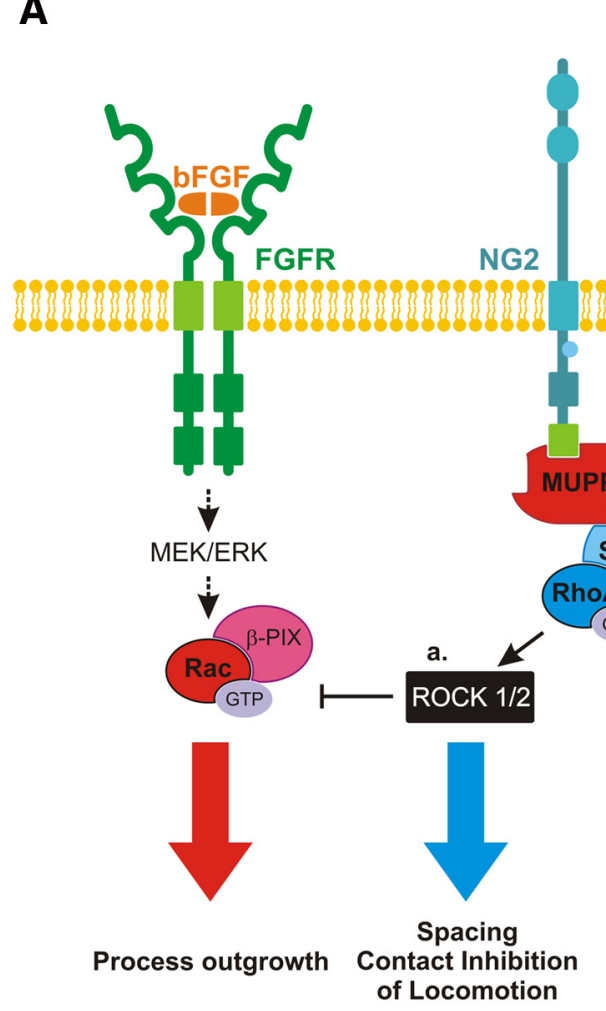

B

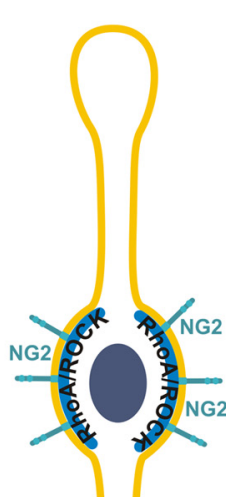

a. Maintenance of bipolar shape

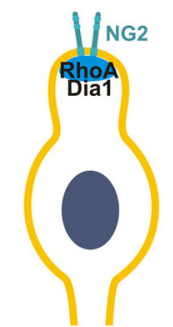

b. Process outgrowth initiation
Process outgrowth Polarization

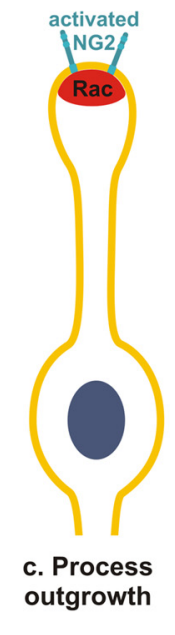

Figure 9. Model of NG2 regulation of Rho GTPases. Signaling pathways regulated by NG2 $(\boldsymbol{A})$ and their impact on process outgrowth $(\boldsymbol{B})$. In its basal state, NG2 interacts with MUPP1 via its PDZ-binding motif and recruits the GEF Syx1, which stimulates RhoA activity and the effectors ROCK1/2 and Dia1. $\boldsymbol{a}$, ROCK 1 and/or ROCK 2 regulate cell spacing; ROCK 2 inhibits Rac activation. As a consequence, NG2-dependent RhoA activity inhibits process outgrowth stimulation by bFGF. $\boldsymbol{b}$, RhoA-activated Dia1 initiates process outgrowth dependent on NG2 phosphorylation and regulates polarization. c, Phosphorylation of NG2 on Thr-2256 by PKC $\alpha$ switches its downstream signaling pathways. The close similarity between PATJ and its ortholog MUPP1 (Adachi et al., 2009), known to interact with NG2 (Barritt et al., 2000), suggests that PATJ could interact with the phosphorylated form of NG2. PATJ binds to Pals1 (Roh et al., 2002): in OPC NG2 could thus associate with the CRB complex via these proteins. The CRB complex interacts with the PAR complex (Lemmers et al., 2004; Shin et al., 2007) and stimulates Rac activity via the GEF Tiam1(Nishimura et al., 2005; Iden and Collard, 2008). Thus NG2-dependent Rac activity regulates process outgrowth and polarization. Proteins and signaling pathways, which were not analyzed in the present study, are drawn with dotted lines.

processes, correlating with its effect on chemokinesis. At 5 and 10 $\mathrm{ng} / \mathrm{ml}$, when cells bearing three processes are the major population, bFGF increased random migration, whereas at $20 \mathrm{ng} / \mathrm{ml}$, when cells bear no processes, bFGF no longer promoted random migration. These results correspond to the known effect of Rac activity on cellular morphology and motility: low Rac activity favors bipolar shape and high migration persistence; higher Rac

activity increases the number of process protrusions and favors random migration; very high levels of activated Rac induces the formation of a lamellae all around the cell, which inhibits migration (Pankov et al., 2005). Since bipolar morphology is optimal for directional migration, the switch to processes slows down migration toward the chemoattractant and would participate in the decrease of chemotaxis to bFGF associated with NG2 downregulation.

Gliosis and production of bFGF are observed in inflammatory lesions such as in multiple sclerosis or lesions such as stab wounds (do Carmo Cunha et al., 2007; Clemente et al., 2011; Robel et al., 2011). We observed a gradient of bFGF in the lesioned hemisphere of adult mice, with the highest concentration in the border zone adjacent to the stab wound. The higher degree of polarization of OPC in WT mice compared with NG2-/ - mice in the border zone, containing abundant bFGF, is consistent with the ability of NG2 to maintain Olineu polarity in high bFGF concentrations. An environment saturated with bFGF favors random migration as it attracts cells in many directions. In such conditions, NG2 would promote directional migration necessary for OPC to reach the center of the wound. We have shown that the same concentration of bFGF induces a stronger Rac activity in cells with NG2 downregulation. Since NG2 downregulation lowers the threshold of bFGF necessary for Rac activation, it would explain why NG2-/- OPC appear attracted toward the wound in the lateral zone where bFGF levels are lower. Therefore, the low concentration of bFGF would stimulate Rac activity in NG2-/OPC to a level suitable for chemotaxis, whereas in WT mice OPC do not polarize as these bFGF levels are insufficient to stimulate Rac activity to levels that promote migration. An increased number of OPC in the border zone of stab wounds has been reported and linked to the control of proliferation by NG2 (Alonso, 2005; Kucharova et al., 2011). Our results suggest that NG2 could also play a role in this increase by restricting OPC recruitment to the environment close to the lesion. In contrast to wounds, NG2 ablation results in only discreet effects during development, thus explaining the paucity of publications reporting consequences of NG2 ablation on migration in vivo. A delayed expansion of OPC was observed in the early postnatal development of NG2 knock-out mice (Kucharova and Stallcup, 2010). Indeed, we found no effect of NG2 depletion on the percentage of polarized OPC in the RMS of p15 mice. 


\section{NG2 promotes constitutive RhoA activity at the cell cortex via the MUPP1/Syx1 complex}

Our results demonstrate that NG2 promotes constitutive RhoA activity at the cell periphery in a layer $60-80 \mathrm{~nm}$ thick. The cortical/subcortical intensity ratio measured in Oli-neu cells transfected with siRNA control was twice the ratio measured in cells with NG2 downregulation. This effect of NG2 is probably responsible for the ROCK-dependent inhibition of clustering of OPC.

Upstream regulators of RhoA such as Fyn kinase have been shown to induce process extension and morphological differentiation in OPC by inhibiting RhoA (Liang et al., 2004). In contrast, NG2 maintains the undifferentiated shape of OPC by RhoA stimulation. This role can be compared with the regulation of neurite outgrowth by RhoGTPases. RhoA inhibition or expression of a dominant-negative form of RhoA enhances the stimulation of neurite outgrowth by NGF and dbcAMP, whereas stimulation of RhoA by LPA or expression of an active form of RhoA inhibits such neurite outgrowth (Sebök et al., 1999; Jeon et al., 2012). These effects of RhoA rely on the inhibition of Rac mediated by ROCK (Yamaguchi et al., 2001). It was further demonstrated that neurite retraction upon LPA addition requires membrane localization of RhoA (Kranenburg et al., 1997). The stimulation of the RhoA/ROCK pathway by NG2 at the cell periphery of OPC may thus generate an inhibitory effect on process protrusion. Release of this regulation results in increased activation of Rac following bFGF treatment, yielding multipolar OPC rather than bipolar cells. In the absence of bFGF, impairment of NG2 signaling does not seem to affect cell morphology but it disturbs polarity establishment in migration, as is seen in centrosome reorientation assays. The effect of the impairment of NG2/ RhoA signaling pathway in OPC could be similar to the way that RhoA downregulation disrupts T-cell polarity by preventing leading edge formation and affecting localization of polarity markers (Heasman et al., 2010).

Downregulation of the PDZ protein MUPP1 and its associated GEF Syx 1 had similar effects on the morphology of Oli-neu treated with $10 \mathrm{ng} / \mathrm{ml}$ bFGF to NG2 downregulation: the dominant population switched from cells bearing two to cells bearing three processes. Moreover, as for NG2, both MUPP1 and Syx1 downregulation seemed to decrease RhoA activity fitting with their reported associated role in RhoA regulation (Estévez et al., 2008; Ernkvist et al., 2009; Lin et al., 2012). The interaction of NG2 with MUPP1 (Barritt et al., 2000) and the coimmunoprecipitation of Syx1 with NG2 lead us to propose that NG2 stimulates RhoA through interaction with the MUPP1/Syx1 complex (Fig. 9).

\section{The Thr-2256-phosphorylated form of NG2 activates Rac via the CRB and PAR polarity complexes}

GTPase pull down demonstrated that the mutant NG2delT2256E (mimicking threonine phosphorylation) stimulates Rac activity. As suggested by the recruitment of ezrin in processes, the NG2 phosphomutant was able to stimulate process outgrowth without addition of growth factors such as bFGF. Indeed, $>50 \%$ of the Oli-neu cells expressing this construct exhibited at least three processes. This multiprocess shape could thus explain the effect of NG2del-T2256E in increasing bFGF-dependent chemokinesis. In our experiments this morphology resulted from an overexpression of the NG2 phosphomutant. In vivo, phosphorylation of NG2 may well result in a lower level of activated Rac asymmetrically localized according to local stimuli. Balanced signaling may thus regulate front-rear polarity by promoting formation of the leading edge of the cell.
We have shown that downregulation of components of the CRB and PAR polarity complexes as well as Tiam 1 were able to counteract the effect of the NG2 phospho-mimetic construct on cell shape, returning Oli-neu cells to a bipolar shape. We confirmed with GTPase pull downs that PATJ and the GEF Tiam1 were transducing the activation of Rac by NG2. Finally, the coimmunoprecipitation of Pals1 with NG2del-T2256E suggests that specifically the phosphorylated form of NG2 interacts with the CRB complex. These lead us to propose a novel model describing how NG2 activates Rac (Fig. 9Ac, $B c$ ). Initially, $\mathrm{PKC} \alpha$ phosphorylates Thr-2256 in the cytoplasmic domain of NG2 (Makagiansar et al., 2004). Phosphorylated NG2 interacts with the CRB complex, which recruits the PAR/Tiam1 complex and stimulates process outgrowth via Rac activation. This signaling pathway will induce the formation of a leading front to orientate cell migration.

Surprisingly, MUPP1, Syx1, and Dia1 downregulation abolished the effect of NG2del-T2256E on Oli-neu cell shape, but this effect was independent of Rac. It is established that RhoA orchestrates the initial events of membrane protrusion, preceding Cdc42 and Rac1 action (Kurokawa et al., 2005; Pertz et al., 2006; Machacek et al., 2009), and RhoA could initiate membrane ruffling via its effector Dial (Kurokawa and Matsuda, 2005). The Thr-2256 phosphorylated form of NG2 would thus cooperate with an initial activation of RhoA and Dial by the nonphosphorylated form of NG2 to promote process protrusion (Fig. 9Ab, $B b)$. However, we found this putative initiator role only in cooperation with the phosphorylated form of NG2, whereas bFGF does not need NG2 to stimulate process outgrowth, arguing for the specific role of the nonphosphorylated form of NG2 in process outgrowth initiation.

Our work reveals that NG2 is a core organizer of the activity and localization of Rho GTPases in the cell. It elucidates how $\mathrm{NG} 2$ regulates migration of OPC and aids in understanding how NG2 stimulates invasiveness of glioma and melanoma tumors. The recruitment of polarity complex proteins by NG2 may also contribute to the control of asymmetric segregation of EGFR by NG2 during OPC mitosis (Sugiarto et al., 2011).

\section{References}

Adachi M, Hamazaki Y, Kobayashi Y, Itoh M, Tsukita S, Furuse M, Tsukita S (2009) Similar and distinct properties of MUPP1 and Patj, two homologous PDZ domain-containing tight-junction proteins. Mol Cell Biol 29: 2372-2389. CrossRef Medline

Adamson P, Paterson HF, Hall A (1992) Intracellular localization of the P21rho proteins. J Cell Biol 119:617-627. CrossRef Medline

Aguirre A, Gallo V (2004) Postnatal neurogenesis and gliogenesis in the olfactory bulb from NG2-expressing progenitors of the subventricular zone. J Neurosci 24:10530-10541. CrossRef Medline

Aguirre A, Dupree JL, Mangin JM, Gallo V (2007) A functional role for EGFR signaling in myelination and remyelination. Nat Neurosci 10:9901002. CrossRef Medline

Alonso G (2005) NG2 proteoglycan-expressing cells of the adult rat brain: possible involvement in the formation of glial scar astrocytes following stab wound. Glia 49:318-338. CrossRef Medline

Arrieumerlou C, Meyer T (2005) A local coupling model and compass parameter for eukaryotic chemotaxis. Dev Cell 8:215-227. CrossRef Medline

Auvinen E, Kivi N, Vaheri A (2007) Regulation of ezrin localization by Rac1 and PIPK in human epithelial cells. Exp Cell Res 313:824-833. CrossRef Medline

Bacon C, Lakics V, Machesky L, Rumsby M (2007) N-WASP regulates extension of filopodia and processes by oligodendrocyte progenitors, oligodendrocytes, and Schwann cells-implications for axon ensheathment at myelination. Glia 55:844-858. CrossRef Medline

Barres BA (2008) The mystery and magic of glia: a perspective on their roles in health and disease. Neuron 60:430-440. CrossRef Medline

Barritt DS, Pearn MT, Zisch AH, Lee SS, Javier RT, Pasquale EB, Stallcup WB 
(2000) The multi-PDZ domain protein MUPP1 is a cytoplasmic ligand for the membrane-spanning proteoglycan NG2. J Cell Biochem 79:213224. CrossRef Medline

Bauer NG, Richter-Landsberg C, Ffrench-Constant C (2009) Role of the oligodendroglial cytoskeleton in differentiation and myelination. Glia 57: 1691-1705. CrossRef Medline

Benninger Y, Thurnherr T, Pereira JA, Krause S, Wu X, Chrostek-Grashoff A, Herzog D, Nave KA, Franklin RJ, Meijer D, Brakebusch C, Suter U, Relvas JB (2007) Essential and distinct roles for cdc42 and racl in the regulation of Schwann cell biology during peripheral nervous system development. J Cell Biol 177:1051-1061. CrossRef Medline

Binamé F, Lassus P, Hibner U (2008) Transforming growth factor beta controls the directional migration of hepatocyte cohorts by modulating their adhesion to fibronectin. Mol Biol Cell 19:945-956. Medline

Binamé F, Pawlak G, Roux P, Hibner U (2010) What makes cells move: requirements and obstacles for spontaneous cell motility. Mol Biosyst 6:648-661. CrossRef Medline

Boroviak T, Rashbass P (2011) The apical polarity determinant Crumbs 2 is a novel regulator of ESC-derived neural progenitors. Stem Cells 29:193205. CrossRef Medline

Campoli M, Ferrone S, Wang X (2010) Functional and clinical relevance of chondroitin sulfate proteoglycan 4. Adv Cancer Res 109:73-121. CrossRef Medline

Carmona-Fontaine C, Matthews HK, Kuriyama S, Moreno M, Dunn GA, Parsons M, Stern CD, Mayor R (2008) Contact inhibition of locomotion in vivo controls neural crest directional migration. Nature 456:957961. CrossRef Medline

Chatterjee N, Stegmüller J, Schätzle P, Karram K, Koroll M, Werner HB, Nave KA, Trotter J (2008) Interaction of syntenin-1 and the NG2 proteoglycan in migratory oligodendrocyte precursor cells. J Biol Chem 283:83108317. CrossRef Medline

Clemente D, Ortega MC, Arenzana FJ, de Castro F (2011) FGF-2 and Anosmin-1 are selectively expressed in different types of multiple sclerosis lesions. J Neurosci 31:14899-14909. CrossRef Medline

Cotter L, Ozçelik M, Jacob C, Pereira JA, Locher V, Baumann R, Relvas JB, Suter U, Tricaud N (2010) Dlg1-PTEN interaction regulates myelin thickness to prevent damaging peripheral nerve overmyelination. Science 328:1415-1418. CrossRef Medline

Czopka T, Von Holst A, Schmidt G, Ffrench-Constant C, Faissner A (2009) Tenascin $\mathrm{C}$ and tenascin $\mathrm{R}$ similarly prevent the formation of myelin membranes in a RhoA-dependent manner, but antagonistically regulate the expression of myelin basic protein via a separate pathway. Glia 57: 1790-1801. CrossRef Medline

Dietrich KA, Schwarz R, Liska M, Grass S, Menke A, Meister M, Kierschke G, Längle C, Genze F, Giehl K (2009) Specific induction of migration and invasion of pancreatic carcinoma cells by RhoC, which differs from RhoA in its localisation and activity. Biol Chem 390:1063-1077. Medline

Dimou L, Simon C, Kirchhoff F, Takebayashi H, Götz M (2008) Progeny of Olig2-expressing progenitors in the gray and white matter of the adult mouse cerebral cortex. J Neurosci 28:10434-10442. CrossRef Medline

do Carmo Cunha J, de Freitas Azevedo Levy B, de Luca BA, de Andrade MS, Gomide VC, Chadi G (2007) Responses of reactive astrocytes containing S100beta protein and fibroblast growth factor- 2 in the border and in the adjacent preserved tissue after a contusion injury of the spinal cord in rats: implications for wound repair and neuroregeneration. Wound Repair Regen 15:134-146. CrossRef Medline

Eisenmann KM, McCarthy JB, Simpson MA, Keely PJ, Guan JL, Tachibana K, Lim L, Manser E, Furcht LT, Iida J (1999) Melanoma chondroitin sulphate proteoglycan regulates cell spreading through Cdc42, Ack-1 and p130cas. Nat Cell Biol 1:507-513. CrossRef Medline

Ernkvist M, Luna Persson N, Audebert S, Lecine P, Sinha I, Liu M, Schlueter M, Horowitz A, Aase K, Weide T, Borg JP, Majumdar A, Holmgren L (2009) The Amot/Patj/Syx signaling complex spatially controls RhoA GTPase activity in migrating endothelial cells. Blood 113:244-253. CrossRef Medline

Estévez MA, Henderson JA, Ahn D, Zhu XR, Poschmann G, Lübbert H, Marx R, Baraban JM (2008) The neuronal RhoA GEF, Tech, interacts with the synaptic multi-PDZ-domain-containing protein, MUPP1. J Neurochem 106:1287-1297. CrossRef Medline

Etienne-Manneville S (2006) In vitro assay of primary astrocyte migration as a tool to study Rho GTPase function in cell polarization. Methods Enzymol 406:565-578. CrossRef Medline
Etienne-Manneville S (2008) Polarity proteins in migration and invasion. Oncogene 27:6970-6980. CrossRef Medline

Etienne-Manneville S, Hall A (2001) Integrin-mediated activation of Cdc42 controls cell polarity in migrating astrocytes through PKCzeta. Cell 106: 489-498. CrossRef Medline

Fukata M, Nakagawa M, Kaibuchi K (2003) Roles of Rho-family GTPases in cell polarisation and directional migration. Curr Opin Cell Biol 15:590597. CrossRef Medline

Goh WI, Sudhaharan T, Lim KB, Sem KP, Lau CL, Ahmed S (2011) Rif$\mathrm{mDial}$ interaction is involved in filopodium formation independent of Cdc42 and Rac effectors. J Biol Chem 286:13681-13694. CrossRef Medline

Hall A, Lalli G (2010) Rho and Ras GTPases in axon growth, guidance, and branching. Cold Spring Harb Perspect Biol 2:a001818. CrossRef Medline

Heasman SJ, Carlin LM, Cox S, Ng T, Ridley AJ (2010) Coordinated RhoA signaling at the leading edge and uropod is required for $\mathrm{T}$ cell transendothelial migration. J Cell Biol 190:553-563. CrossRef Medline

Hodgson L, Shen F, Hahn K (2010) Biosensors for characterizing the dynamics of rho family GTPases in living cells. Curr Protoc Cell Biol Chapter 14:Unit 14 11.1-26. CrossRef Medline

Iden S, Collard JG (2008) Crosstalk between small GTPases and polarity proteins in cell polarization. Nat Rev Mol Cell Biol 9:846-859. CrossRef Medline

Ishiuchi T, Takeichi M (2011) Willin and Par3 cooperatively regulate epithelial apical constriction through aPKC-mediated ROCK phosphorylation. Nat Cell Biol 13:860-866. CrossRef Medline

Jeon CY, Moon MY, Kim JH, Kim HJ, Kim JG, Li Y, Jin JK, Kim PH, Kim HC, Meier KE, Kim YS, Park JB (2012) Control of neurite outgrowth by RhoA inactivation. J Neurochem 120:684-698. CrossRef Medline

Jung M, Krämer E, Grzenkowski M, Tang K, Blakemore W, Aguzzi A, Khazaie K, Chlichlia K, von Blankenfeld G, Kettenmann H (1995) Lines of murine oligodendroglial precursor cells immortalized by an activated neu tyrosine kinase show distinct degrees of interaction with axons in vitro and in vivo. Eur J Neurosci 7:1245-1265. CrossRef Medline

Karram K, Goebbels S, Schwab M, Jennissen K, Seifert G, Steinhäuser C, Nave KA, Trotter J (2008) NG2-expressing cells in the nervous system revealed by the NG2-EYFP-knockin mouse. Genesis 46:743-757. CrossRef Medline

Krämer EM, Koch T, Niehaus A, Trotter J (1997) Oligodendrocytes direct glycosyl phosphatidylinositol-anchored proteins to the myelin sheath in glycosphingolipid-rich complexes. J Biol Chem 272:8937-8945. CrossRef Medline

Kranenburg O, Poland M, Gebbink M, Oomen L, Moolenaar WH (1997) Dissociation of LPA-induced cytoskeletal contraction from stress fiber formation by differential localization of RhoA. J Cell Sci 110:2417-2427. Medline

Kucharova K, Stallcup WB (2010) The NG2 proteoglycan promotes oligodendrocyte progenitor proliferation and developmental myelination. Neuroscience 166:185-194. CrossRef Medline

Kucharova K, Chang Y, Boor A, Yong VW, Stallcup WB (2011) Reduced inflammation accompanies diminished myelin damage and repair in the NG2 null mouse spinal cord. J Neuroinflammation 8:158. CrossRef Medline

Kurokawa K, Matsuda M (2005) Localized RhoA activation as a requirement for the induction of membrane ruffling. Mol Biol Cell 16:42944303. CrossRef Medline

Kurokawa K, Nakamura T, Aoki K, Matsuda M (2005) Mechanism and role of localized activation of Rho-family GTPases in growth factorstimulated fibroblasts and neuronal cells. Biochem Soc Trans 33:631634. CrossRef Medline

Lee J, Jung ID, Chang WK, Park CG, Cho DY, Shin EY, Seo DW, Kim YK, Lee HW, Han JW, Lee HY (2005) p85 beta-PIX is required for cell motility through phosphorylations of focal adhesion kinase and p38 MAP kinase. Exp Cell Res 307:315-328. CrossRef Medline

Lemmers C, Michel D, Lane-Guermonprez L, Delgrossi MH, Médina E, Arsanto JP, Le Bivic A (2004) CRB3 binds directly to Par6 and regulates the morphogenesis of the tight junctions in mammalian epithelial cells. Mol Biol Cell 15:1324-1333. Medline

Liang X, Draghi NA, Resh MD (2004) Signaling from integrins to Fyn to Rho family GTPases regulates morphologic differentiation of oligodendrocytes. J Neurosci 24:7140-7149. CrossRef Medline

Lin L, Tran T, Hu S, Cramer T, Komuniecki R, Steven RM (2012) RHGF-2 
is an essential Rho- 1 specific RhoGEF that binds to the multi-PDZ domain scaffold protein MPZ-1 in Caenorhabditis elegans. PLoS One 7:e31499. CrossRef Medline

Liu M, Horowitz A (2006) A PDZ-binding motif as a critical determinant of Rho guanine exchange factor function and cell phenotype. Mol Biol Cell 17:1880-1887. CrossRef Medline

Machacek M, Hodgson L, Welch C, Elliott H, Pertz O, Nalbant P, Abell A, Johnson GL, Hahn KM, Danuser G (2009) Coordination of Rho GTPase activities during cell protrusion. Nature 461:99-103. CrossRef Medline

Mackay DJ, Esch F, Furthmayr H, Hall A (1997) Rho- and rac-dependent assembly of focal adhesion complexes and actin filaments in permeabilized fibroblasts: an essential role for ezrin/radixin/moesin proteins. J Cell Biol 138:927-938. CrossRef Medline

Majumdar M, Vuori K, Stallcup WB (2003) Engagement of the NG2 proteoglycan triggers cell spreading via rac and p130cas. Cell Signal 15:79-84. CrossRef Medline

Makagiansar IT, Williams S, Dahlin-Huppe K, Fukushi J, Mustelin T, Stallcup WB (2004) Phosphorylation of NG2 proteoglycan by protein kinase $\mathrm{C}$-alpha regulates polarized membrane distribution and cell motility. J Biol Chem 279:55262-55270. CrossRef Medline

Makagiansar IT, Williams S, Mustelin T, Stallcup WB (2007) Differential phosphorylation of NG2 proteoglycan by ERK and PKCalpha helps balance cell proliferation and migration. J Cell Biol 178:155-165. CrossRef Medline

Malliri A, van Es S, Huveneers S, Collard JG (2004) The Rac exchange factor Tiam1 is required for the establishment and maintenance of cadherinbased adhesions. J Biol Chem 279:30092-30098. CrossRef Medline

Matsuo N, Terao M, Nabeshima Y, Hoshino M (2003) Roles of STEF/ Tiam1, guanine nucleotide exchange factors for Racl, in regulation of growth cone morphology. Mol Cell Neurosci 24:69-81. CrossRef Medline

Niehaus A, Stegmüller J, Diers-Fenger M, Trotter J (1999) Cell-surface glycoprotein of oligodendrocyte progenitors involved in migration. J Neurosci 19:4948-4961. Medline

Nishimura T, Yamaguchi T, Kato K, Yoshizawa M, Nabeshima Y, Ohno S, Hoshino M, Kaibuchi K (2005) PAR-6-PAR-3 mediates Cdc42-induced Rac activation through the Rac GEFs STEF/Tiam1. Nat Cell Biol 7:270277. CrossRef Medline

Nishiyama A, Lin XH, Stallcup WB (1995) Generation of truncated forms of the NG2 proteoglycan by cell surface proteolysis. Mol Biol Cell 6:1819-1832. Medline

Nishiyama A, Komitova M, Suzuki R, Zhu X (2009) Polydendrocytes (NG2 cells): multifunctional cells with lineage plasticity. Nat Rev Neurosci 10: 9-22. CrossRef Medline

Pankov R, Endo Y, Even-Ram S, Araki M, Clark K, Cukierman E, Matsumoto K, Yamada KM (2005) A Rac switch regulates random versus directionally persistent cell migration. J Cell Biol 170:793-802. CrossRef Medline

Pertz O, Hodgson L, Klemke RL, Hahn KM (2006) Spatiotemporal dynamics of RhoA activity in migrating cells. Nature 440:1069-1072. CrossRef Medline

Petrie RJ, Doyle AD, Yamada KM (2009) Random versus directionally persistent cell migration. Nat Rev Mol Cell Biol 10:538-549. CrossRef Medline

Ridley AJ (2001) Rho GTPases and cell migration. J Cell Sci 114:2713-2722. Medline

Robel S, Berninger B, Götz M (2011) The stem cell potential of glia: lessons from reactive gliosis. Nat Rev Neurosci 12:88-104. CrossRef Medline

Roh MH, Makarova O, Liu CJ, Shin K, Lee S, Laurinec S, Goyal M, Wiggins R, Margolis B (2002) The Maguk protein, Pals1, functions as an adapter, linking mammalian homologues of Crumbs and Discs Lost. J Cell Biol 157:161-172. CrossRef Medline

Rossman KL, Der CJ, Sondek J (2005) GEF means go: turning on RHO GTPases with guanine nucleotide-exchange factors. Nat Rev Mol Cell Biol 6:167-180. CrossRef Medline

Sala-Valdés M, Gordón-Alonso M, Tejera E, Ibáñez A, Cabrero JR, Ursa A, Mittelbrunn M, Lozano F, Sánchez-Madrid F, Yáñez-M ó M (2012) Association of syntenin-1 with M-RIP polarizes Rac-1 activation during chemotaxis and immune interactions. J Cell Sci 125:1235-1246. CrossRef Medline

Sebök A, Nusser N, Debreceni B, Guo Z, Santos MF, Szeberenyi J, Tigyi G (1999) Different roles for RhoA during neurite initiation, elongation, and regeneration in PC12 cells. J Neurochem 73:949-960. Medline

Shin EY, Shin KS, Lee CS, Woo KN, Quan SH, Soung NK, Kim YG, Cha CI, Kim SR, Park D, Bokoch GM, Kim EG (2002) Phosphorylation of p85 beta PIX, a Rac/Cdc42-specific guanine nucleotide exchange factor, via the Ras/ERK/PAK2 pathway is required for basic fibroblast growth factorinduced neurite outgrowth. J Biol Chem 277:44417-44430. CrossRef Medline

Shin K, Wang Q, Margolis B (2007) PATJ regulates directional migration of mammalian epithelial cells. EMBO Rep 8:158-164. CrossRef Medline

Siebert JR, Osterhout DJ (2011) The inhibitory effects of chondroitin sulfate proteoglycans on oligodendrocytes. J Neurochem 119:176-188. CrossRef Medline

Simon C, Götz M, Dimou L (2011) Progenitors in the adult cerebral cortex: cell cycle properties and regulation by physiological stimuli and injury. Glia 59:869-881. CrossRef Medline

Simons M, Trajkovic K (2006) Neuron-glia communication in the control of oligodendrocyte function and myelin biogenesis. J Cell Sci 119:4381-4389. CrossRef Medline

Stallcup WB, Dahlin-Huppe K (2001) Chondroitin sulfate and cytoplasmic domain-dependent membrane targeting of the NG2 proteoglycan promotes retraction fiber formation and cell polarization. J Cell Sci 114: 2315-2325. Medline

Stallcup WB, Huang FJ (2008) A role for the NG2 proteoglycan in glioma progression. Cell Adh Migr 2:192-201. CrossRef Medline

Stegmüller J, Werner H, Nave KA, Trotter J (2003) The proteoglycan NG2 is complexed with alpha-amino-3-hydroxy-5-methyl-4-isoxazolepropionic acid (AMPA) receptors by the PDZ glutamate receptor interaction protein (GRIP) in glial progenitor cells. Implications for glial-neuronal signaling. J Biol Chem 278:3590-3598. CrossRef Medline

Sugiarto S, Persson AI, Munoz EG, Waldhuber M, Lamagna C, Andor N, Hanecker P, Ayers-Ringler J, Phillips J, Siu J, Lim DA, Vandenberg S, Stallcup W, Berger MS, Bergers G, Weiss WA, Petritsch C (2011) Asymmetry-defective oligodendrocyte progenitors are glioma precursors. Cancer Cell 20:328-340. CrossRef Medline

Sugimoto Y, Taniguchi M, Yagi T, Akagi Y, Nojyo Y, Tamamaki N (2001) Guidance of glial precursor cell migration by secreted cues in the developing optic nerve. Development 128:3321-3330. Medline

van Rossum AG, Aartsen WM, Meuleman J, Klooster J, Malysheva A, Versteeg I, Arsanto JP, Le Bivic A, Wijnholds J (2006) Pals1/Mpp5 is required for correct localization of $\mathrm{Crb} 1$ at the subapical region in polarized Muller glia cells. Hum Mol Genet 15:2659-2672. CrossRef Medline

Vega FM, Fruhwirth G, Ng T, Ridley AJ (2011) RhoA and RhoC have distinct roles in migration and invasion by acting through different targets. J Cell Biol 193:655-665. CrossRef Medline

Vinot S, Anguille C, de Toledo M, Gadea G, Roux P (2008) Analysis of cell migration and its regulation by Rho GTPases and p53 in a threedimensional environment. Methods Enzymol 439:413-424. CrossRef Medline

Yamaguchi Y, Katoh H, Yasui H, Mori K, Negishi M (2001) RhoA inhibits the nerve growth factor-induced Racl activation through Rho-associated kinase-dependent pathway. J Biol Chem 276:18977-18983. CrossRef Medline

Yamamura T, Konola JT, Wekerle H, Lees MB (1991) Monoclonal antibodies against myelin proteolipid protein: identification and characterization of two major determinants. J Neurochem 57:1671-1680. CrossRef Medline

Zhang H, Macara IG (2008) The PAR-6 polarity protein regulates dendritic spine morphogenesis through p190 RhoGAP and the Rho GTPase. Dev Cell 14:216-226. CrossRef Medline

Zhang H, Vutskits L, Calaora V, Durbec P, Kiss JZ (2004) A role for the polysialic acid-neural cell adhesion molecule in PDGF-induced chemotaxis of oligodendrocyte precursor cells. J Cell Sci 117:93-103. CrossRef Medline 